\title{
Aircraft measurements over Europe of an air pollution plume from Southeast Asia - aerosol and chemical characterization
}

\author{
A. Stohl ${ }^{1}$, C. Forster ${ }^{1,2}$, H. Huntrieser ${ }^{2}$, H. Mannstein ${ }^{2}$, W. W. McMillan ${ }^{3}$, A. Petzold ${ }^{2}$, H. Schlager ${ }^{2}$, and \\ B. Weinzierl ${ }^{2}$ \\ ${ }^{1}$ Norwegian Institute for Air Research, Kjeller, Norway \\ ${ }^{2}$ Institut für Physik der Atmosphäre, Deutsches Zentrum für Luft- und Raumfahrt (DLR), Oberpfaffenhofen, Germany \\ ${ }^{3}$ University of Maryland, Baltimore, USA
}

Received: 13 November 2006 - Published in Atmos. Chem. Phys. Discuss.: 5 December 2006

Revised: 2 February 2007 - Accepted: 14 February 2007 - Published: 16 February 2007

\begin{abstract}
An air pollution plume from Southern and Eastern Asia, including regions in India and China, was predicted by the FLEXPART particle dispersion model to arrive in the upper troposphere over Europe on 24-25 March 2006. According to the model, the plume was exported from Southeast Asia six days earlier, transported into the upper troposphere by a warm conveyor belt, and travelled to Europe in a fast zonal flow. This is confirmed by the retrievals of carbon monoxide (CO) from AIRS satellite measurements, which are in excellent agreement with the model results over the entire transport history. The research aircraft DLR Falcon was sent into this plume west of Spain on 24 March and over Southern Europe on 25 March. On both days, the pollution plume was found close to the predicted locations and, thus, the measurements taken allowed the first detailed characterization of the aerosol content and chemical composition of an anthropogenic pollution plume after a nearly hemispheric transport event. The mixing ratios of $\mathrm{CO}$, reactive nitrogen $\left(\mathrm{NO}_{\mathrm{y}}\right)$ and ozone $\left(\mathrm{O}_{3}\right)$ measured in the Asian plume were all clearly elevated over a background that was itself likely elevated by Asian emissions: CO by 17-34 ppbv on average (maximum $60 \mathrm{ppbv}$ ) and $\mathrm{O}_{3}$ by $2-9$ ppbv (maximum $22 \mathrm{ppbv}$ ). Positive correlations existed between these species, and a $\Delta \mathrm{O}_{3} / \Delta \mathrm{CO}$ slope of 0.25 shows that ozone was formed in this plume, albeit with moderate efficiency. Nucleation mode and Aitken particles were suppressed in the Asian plume, whereas accumulation mode aerosols were strongly elevated and correlated with $\mathrm{CO}$. The suppression of the nucleation mode was likely due to the large pre-existing aerosol surface of the transported larger particles. Supermicron particles, likely desert dust, were found in part of the Asian pollution plume and also in surrounding cleaner air. The aerosol light absorption coefficient was enhanced in the plume (average values for individual plume encounters
\end{abstract}

Correspondence to: A. Stohl

(ast@nilu.no)
$0.25-0.70 \mathrm{Mm}^{-1}$ ), as was the fraction of non-volatile Aitken particles. This indicates that black carbon (BC) was an important aerosol component. During the flight on 25 March, which took place on the rear of a trough located over Europe, a mixture of Asian pollution and stratospheric air was found. Asian pollution was mixing into the lower stratosphere, and stratospheric air was mixing into the pollution plume in the troposphere. Turbulence was encountered by the aircraft in the mixing regions, where the thermal stability was low and Richardson numbers were below 0.2. The result of the mixing can clearly be seen in the trace gas data, which are following mixing lines in correlation plots. This mixing with stratospheric air is likely very typical of Asian air pollution, which is often lifted to the upper troposphere and, thus, transported in the vicinity of stratospheric air.

\section{Introduction}

Recently, intercontinental transport of air pollutants has been recognized as an important process affecting the atmospheric chemical composition. Speculations on its relevance were made early (e.g. Andreae et al., 1988) but the first unambiguous examples based on observations were published by Jaffe et al. (1999) for transport from Asia to North America, and by Stohl and Trickl (1999) for transport from North America to Europe. Since these studies, the number of articles documenting the phenomenon and evaluating its impact on ozone and aerosol concentrations goes into the dozens (e.g. Berntsen et al., 1999; Jacob et al., 1999; Wild and Akimoto, 2001; Li et al., 2002; Stohl et al., 2003; Traub et al., 2003; Hudman et al., 2004; Price et al., 2004; Huntrieser et al., 2005; Auvray and Bey, 2005). The relevant transport processes have been identified and, for pollution export from Asia and North America, often involve lifting to the upper troposphere by so-called warm conveyor belts (WCBs) at the eastern seaboards and subsequent transport by fast airstreams

Published by Copernicus GmbH on behalf of the European Geosciences Union. 
in the middle or upper troposphere (Stohl, 2001; Stohl et al., 2002a). The study by Stohl and Trickl (1999) is a textbook example for this process. In addition, deep convection in thunderstorms or mesoscale convective complexes is also important in summer (Wild and Akimoto, 2001).

Much of our current understanding of the impact of intercontinental air pollution transport on the chemical composition of the atmosphere is based on the results of model studies (e.g. Wild and Akimoto, 2001; Li et al., 2002). Observational studies are relatively less numerous but a number of transport events have been described recently (see, e.g., articles in the book by Stohl, 2004). The models are in broad consensus with the observations but their validity for hemispheric transport distances is still uncertain. Another problematic issue with the transport over such long distances is that the mixing of pollution plumes with other air masses becomes important and probably dominant. For instance, mixing of Asian pollution with stratospheric air can occur even before such a plume reaches North America (Cooper et al., 2004a,b). Trickl et al. (2003) observed dry ozone-rich air masses to arrive over Europe, which originated from beyond North America but because of mixing they could not say how much of the ozone was produced in Asian pollution plumes and how much was transported from the stratosphere. The accuracy of global models will depend to a large extent on how well they can treat the mixing between different air masses.

Recently, a so-called Task Force on Hemispheric Transport of Air Pollution (http://www.htap.org/) was founded by the United Nations Economic Commission for Europe (UNECE) under the Convention on Long-range Transboundary Air Pollution, and international partner organisations. This Task Force shall further our understanding of hemisphericscale air pollution transport and explore its implications for environmental policies. This can be achieved only through the extensive use of chemistry transport models and climate chemistry models. Yet, observations of truly hemisphericscale transport events, which must serve as the ultimate benchmarks for the models, are lacking. For instance, we are not aware of a study describing the transport of an anthropogenic air pollution plume from Asia across the North Pacific, North America, and the North Atlantic to Europe, despite the fact that model calculations suggest a substantial impact of Asian emissions on carbon monoxide (e.g. Pfister et al., 2004) and ozone levels (e.g. Auvray and Bey, 2005) over Europe. Asian pollution over Europe has only been documented after taking the alternative shorter but presumably less important pathway involving westward transport with the monsoon circulation from India to Africa and the Mediterranean (Lelieveld et al., 2002; Lawrence et al., 2003; Traub et al., 2003). Regarding transport with the westerlies, Damoah et al. (2004) reported a case where a smoke plume originating from boreal forest fires burning in Siberia was transported across North America to Europe. The transport of the smoke was clearly visible in satellite imagery and, thus, the source attribution was relatively straightforward. Grousset et al. (2003) reported a likely case of dust transport from Asia to Europe, again a case with a rather unique signature. Pollution produced by fossil fuel combustion (FFC) in Asia is more difficult to detect over Europe because the concentrations involved are typically lower and, thus, such plumes cannot easily be tracked from space.

As a result of the strong lifting of polluted air masses at the eastern seaboard of Asia, the biggest chance of successfully identifying such a pollution plume over Europe is in the upper troposphere (Wild and Akimoto, 2001; Stohl et al., 2002a), requiring measurements with an aircraft. However, current models accumulate considerable errors over hemispheric transport distances and, thus, guiding a research aircraft into such a plume still poses a major challenge for modelers. In this paper, we present the first unambiguous observation of transport of FFC emissions from Southeast Asia via the westerlies to Europe. We describe how the Asian pollution plume was targeted over Europe with a research aircraft and characterize its chemical composition and aerosol content.

\section{Methods}

\subsection{Instrumentation}

We used the DLR (Deutsches Zentrum für Luft- und Raumfahrt) research aircraft Falcon with an extensive instrumentation for in situ measurements of trace gases and aerosol microphysical properties as well as meteorological parameters, as summarized in Table 1. Nitric oxide (NO) and the sum of reactive nitrogen compounds $\left(\mathrm{NO}_{\mathrm{y}}\right)$ were measured using a chemiluminescence technique (Schlager et al., 1997; Ziereis et al., 1999). Individual $\mathrm{NO}_{\mathrm{y}}$ compounds were catalytically reduced to NO on the surface of a heated gold converter with addition of $\mathrm{CO}$. The inlet tube for air sampling was oriented rearward and heated to $30^{\circ} \mathrm{C}$ to avoid sampling of particles with diameters larger than about $1 \mu \mathrm{m}$ and adsorption of nitric acid on the wall of the sampling tube, respectively. The accuracy of the $\mathrm{NO}$ and $\mathrm{NO}_{\mathrm{y}}$ measurements is 8 and $15 \%$, respectively, for a time resolution of $1 \mathrm{~s}$. Detections of $\mathrm{CO}$ and $\mathrm{O}_{3}$ were made using vacuum resonance fluorescence in the fourth positive band of CO (Gerbig et al., 1996) and UV absorption (Thermo Electron Corporation, Model 49), respectively. The accuracy of the $\mathrm{CO}$ and $\mathrm{O}_{3}$ measurements is 10 and $5 \%$ for a time resolution of $5 \mathrm{~s}$.

The aerosol instrumentation was capable of measuring particle size ranges from the small particles relevant for particle formation processes $\left(D_{p}<0.02 \mu \mathrm{m}\right)$, to the optically active background Aitken and accumulation mode particles $(0.05 \mu \mathrm{m}<\mathrm{D}<1-2 \mu \mathrm{m})$, and to the coarse mode dust or sea salt particles $\left(D_{p}>1 \mu \mathrm{m}\right)$. It consisted of four condensation particle counters (CPC) operated at different lower cutoff diameters (Schröder and Ström, 1997), diffusion screen 
Table 1. Instrumentation on board the research aircraft Falcon during MEGAPLUME.

\begin{tabular}{|c|c|}
\hline Property & Instrumentation \\
\hline \multicolumn{2}{|l|}{ Trace gase } \\
\hline $\mathrm{NO} / \mathrm{NO}_{\mathrm{y}}$ & Chemiluminescence detector \\
\hline $\mathrm{CO}$ & VUV fluorescence \\
\hline $\mathrm{O}_{3}$ & UV absorption \\
\hline \multicolumn{2}{|l|}{ Aerosol properties } \\
\hline $\begin{array}{l}\text { Number concentration; } \\
\text { size distribution of ultrafine particles }\end{array}$ & $\begin{array}{l}\text { Condensation Particle Counters }(\mathrm{CPC}) \\
\quad \text { operated at lower cut-off diameters } \mathrm{D}_{\min }=0.004 \text { and } 0.010 \mu \mathrm{m}\end{array}$ \\
\hline \multicolumn{2}{|r|}{ 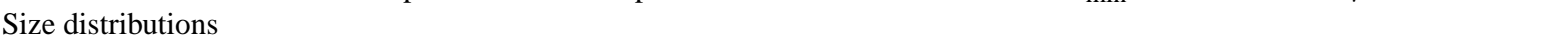 } \\
\hline Dry state, accumulation mode & Passive Cavity Aerosol Spectrometer Probe PCASP-100X: $0.1 \mu \mathrm{m}<\mathrm{D}<3.0 \mu \mathrm{m}$ \\
\hline Ambient state, accumulation + coarse mode & Forward Scattering Spectrometer Probe FSSP 300: $0.3 \mu \mathrm{m}<\mathrm{D}<20 \mu \mathrm{m}$ \\
\hline $\begin{array}{l}\text { Volume fraction of } \\
\text { volatile/refractory particles }\end{array}$ & $\begin{array}{l}\text { Thermodenuder }\left(\mathrm{T}=20^{\circ} \mathrm{C} / 250^{\circ} \mathrm{C}\right) \text { connected to CPCs operated at } \\
\mathrm{D}_{\min }=0.014 \text {, and } 0.080 \mu \mathrm{m}(\mathrm{CPC} \& \text { Diffusion Screen Separator DS })\end{array}$ \\
\hline Aerosol optical properties & \\
\hline $\begin{array}{l}\text { Volume absorption coefficient, } \lambda=0.55 \mu \mathrm{m} \\
\text { Meteorological parameters }\end{array}$ & Particle Soot Absorption Photometer (PSAP) \\
\hline $\mathrm{T}, \mathrm{p}, \mathrm{RH}, 3-\mathrm{D}$ wind velocity & Falcon standard instrumentation \\
\hline
\end{tabular}

separators (Feldpausch et al., 2006), one thermodenuder with two channels operated at $20^{\circ} \mathrm{C}$ and $250^{\circ} \mathrm{C}$ (Engler et al., 2006), and two optical particle counters (passive cavity aerosol spectrometer probe (PCASP 100X); forward scattering spectrometer probe (FSSP 300)). The number concentrations of nucleation mode, Aitken mode and accumulation mode particles were determined from CPC and PCASP100X data. The fractions of volatile particles of the nucleation mode, Aitken mode and accumulation mode were determined from two CPC instruments connected to heated and non-heated sampling lines of equal lengths, respectively. The heating temperature of the sampling line was set to $250^{\circ} \mathrm{C}$ for separating volatile components of sulfuric acid-like and ammonium sulfate-like behavior from non-volatile or refractory particle components like BC, sea salt, dust and soil material (Engler et al., 2006). CPC instruments were operated with nominal minimum threshold diameters (50\% response probability) of 4 and $10 \mathrm{~nm}$ for the total aerosol and of 14 and $80 \mathrm{~nm}$ for the non-volatile aerosol. The latter cut-off diameter of $80 \mathrm{~nm}$ was achieved by a CPC equipped with a diffusion screen separator containing three screens (Feldpausch et al., 2006). Size distributions of the accumulation and coarse mode were inferred from a combined analysis of PCASP100X and FSSP-300 data. FSSP-300 data were also used for the identification of in-cloud sequences. If in a humid air mass the number concentration in the size range $D_{p}>3 \mu \mathrm{m}$ exceeded $1 \mathrm{~cm}^{-3}$, sequences were labeled in-cloud.

A particle soot absorption photometer (PSAP) (Bond et al., 1999) was used to measure the aerosol absorption coefficient $\sigma_{a p}$ at $550 \mathrm{~nm}$. Based on previous experience (Petzold et al., 2002), only constant-altitude flight sequences out of clouds were used for the data analysis to avoid measurement artifacts due to pressure changes in the sampling line during ascent and descent. The limitation to out-of- cloud sequences avoids measurement artifacts due to humidity effects on the filter transmission function (Arnott et al., 2003). The correction function proposed by Bond et al. (1999) was applied. Since no direct measurement of the aerosol light scattering coefficient was available, the scattering coefficient correction was performed assuming an average single-scattering albedo of 0.95 . The detection limit was set empirically to $0.1 \mathrm{sMm}^{-1}$ based on previous experience (Petzold et al., 2002). The $\sigma_{a p}$ values can be converted to equivalent $\mathrm{BC}(\mathrm{EBC})$ mass concentrations by dividing by a mass-specific absorption coefficient of $8 \mathrm{~m}^{2} \mathrm{~g}^{-1}$ (Bond and Bergstrom, 2006).

\subsection{Emission information}

For information on FFC emissions in Asia, we used the EDGAR 3.2 Fast Track 2000 global inventory of CO and $\mathrm{NO}_{\mathrm{x}}$ emissions (Olivier et al., 2001). North American emissions were based on the point, onroad, nonroad and area sources from the U.S. EPA National Emissions Inventory, base year 1999 with updates for 2005, with spatial partitioning of area sources at $4 \mathrm{~km}$ resolution (Frost et al., 2006). For Europe, we used the expert emissions taken from the UNECE/EMEP (United Nations Economic Commission for Europe/Co-operative Programme for Monitoring and Evaluation of Long Range Transmission of Air Pollutants in Europe) emission database for the year 2003. These data are based on official country reports with adjustments made by experts and are available at $0.5^{\circ}$ resolution from http://www.emep.int. In addition, estimates were also made for biomass burning (BB) emissions of $\mathrm{CO}$, using daily fire detections (resolution about $1 \mathrm{~km}$ ) from the MODIS instruments onboard the Aqua and Terra satellites (Giglio et al., 2003), information on land cover at $1 \mathrm{~km}$ resolution (Hansen 
et al., 2000), and an algorithm recently described by Stohl et al. (2006). BB emission estimates are highly uncertain by an estimated factor of three because no information on the size of the fires is available.

\subsection{Model simulations}

Simulations were made using the Lagrangian particle dispersion model FLEXPART (Stohl et al., 1998; Stohl and Thomson, 1999; Stohl et al., 2005) (see http://zardoz.nilu. no/ andreas/flextra+flexpart.html). FLEXPART releases socalled tracer particles at emission sources and calculates their trajectories using the mean winds interpolated from the meteorological input fields plus random motions representing turbulence. For moist convective transport, the scheme of Emanuel and Živković-Rothman (1999), as described and tested by Forster et al. (2007), is used. FLEXPART was used previously to study intercontinental transport of air pollutants generated by FFC (Stohl and Trickl, 1999; Stohl et al., 2002a, 2003; Forster et al., 2004) and BB (Forster et al., 2001; Damoah et al., 2004).

During the measurement campaign, FLEXPART served as a forecast model, in order to guide the aircraft into pollution plumes of interest. The forecasts, made four times a day, were similar to the ones described in Forster et al. (2004) and were using input data from the National Centers for Environmental Prediction Global Forecast System (GFS) model with $1^{\circ} \times 1^{\circ}$ resolution and 26 pressure levels. For post-mission calculations, FLEXPART was driven also with operational analyses from the European Centre for Medium-Range Weather Forecasts (ECMWF) (White, 2002) with $1^{\circ} \times 1^{\circ}$ resolution (derived from T319 spectral truncation) and two nests $\left(108-27^{\circ} \mathrm{W}, 9-54^{\circ} \mathrm{N} ; 27^{\circ} \mathrm{W}-54^{\circ} \mathrm{E}\right.$, $35-81^{\circ} \mathrm{N}$ ) with $0.36^{\circ} \times 0.36^{\circ}$ resolution (derived from T799 spectral truncation). There are 23 ECMWF model levels below $3000 \mathrm{~m}$, and 91 in total. In addition to the analyses at 00:00, 06:00, 12:00 and 18:00 UTC, 3-h forecasts at intermediate times (03:00, 09:00, 15:00, 21:00 UTC) were used. Most of the results shown in this paper are from the simulations using the ECMWF data but comparisons with results from GFS-driven simulations will also be presented.

Transport of $\mathrm{CO}$ and $\mathrm{NO}_{\mathrm{x}}$ FFC emission tracers was calculated separately for the source regions Asia, North America and Europe, respectively. For every tracer, 700000 particles per day were injected between 0 and $100 \mathrm{~m}$ above the ground for area sources and between $100 \%$ and $120 \%$ of the stack altitude for point sources. The particles were carried for 20 days, after which they were removed from the simulation. FLEXPART is a pure transport model and no removal processes were considered here. Thus, the only purpose of the model simulations is to identify the regions affected by pollution plumes and to understand the pollution transport in relation to the synoptic situation.

A special feature of FLEXPART is the possibility to run it backward in time to produce information on the spatial dis- tribution of sources contributing to a particular measurement (Stohl et al., 2003; Seibert and Frank, 2004). Backward simulations were made from small segments along flight tracks. Segments were generated when the aircraft changed its position by more than $0.18^{\circ}$ in either longitude or latitude, or changed altitude by more than $8 \mathrm{hPa}$ below $850 \mathrm{hPa}, 12 \mathrm{hPa}$ between 850 and $700 \mathrm{hPa}$, and $15 \mathrm{hPa}$ above. $40000 \mathrm{par}-$ ticles were released per segment and were followed backward in time for 20 days, forming what we call a retroplume, to calculate a so-called potential emission sensitivity (PES) function, as described by Seibert and Frank (2004) and Stohl et al. (2003). The word "potential" here indicates that this sensitivity is based on transport alone, ignoring removal processes that would reduce the sensitivity. The value of the PES function (in units of $\mathrm{s} \mathrm{kg}^{-1}$ ) in a particular grid cell is proportional to the particle residence time in that cell. It is a measure for the simulated mixing ratio at the receptor that a source of unit strength $\left(1 \mathrm{~kg} \mathrm{~s}^{-1}\right)$ in the respective grid cell would produce. For consistency with the forward simulations, we report PES values for a so-called footprint layer $0-100 \mathrm{~m}$ above ground. Folding (i.e., multiplying) the PES footprint with the distribution of the emission flux densities (in units of $\mathrm{kg} \mathrm{m}^{-2} \mathrm{~s}^{-1}$ ) from the FFC and BB inventories yields a so-called potential source contribution (PSC) map, that is the geographical distribution of sources contributing to the simulated mixing ratio at the receptor. Spatial integration of the PSC map finally gives the simulated mass mixing ratio for the flight segment. Since the backward model output was generated at daily intervals, the timing (i.e., the age) of the contributing emissions is also known.

\subsection{AIRS CO retrievals}

For comparison with the model results, $\mathrm{CO}$ was retrieved from the Atmospheric InfraRed Sounder (AIRS) in orbit onboard NASA's Aqua satellite. All AIRS retrievals for a given day were binned to a $1^{\circ} \times 1^{\circ}$ grid to produce daily $\mathrm{CO}$ maps. The prelaunch AIRS CO retieval algorithm was employed using the AFGL standard CO profile as the first guess and the AIRS team retrieval algorithm PGE v4.0. Here we plot AIRS upper tropospheric $\mathrm{CO}$ mixing ratios for a reference height of $350 \mathrm{hPa}$ since both FLEXPART and the aircraft in situ measurements indicate the Asian plume was transported in the upper troposphere. The AIRS CO retrievals are consistent with this, but lack sufficient vertical specificity to be conclusive (McMillan et al., 2005, 2007¹).

\footnotetext{
${ }^{1}$ McMillan, W. W., Warner, J. X., McCourt Comer, M., Maddy, E., Chu, A., Sparling, L., Eloranta, E., Hoff, R., Sachse, G., Barnet, C., Razenkov, I., and Wolf, W.: AIRS views of transport from 1023 July 2004 Alaskan/Canadian fires: Correlation of AIRS CO and MODIS AOD and comparison of AIRS CO retrievals with DC-8 in situ measurements during INTEX-NA/ICARTT, J. Geophys. Res., submitted, 2007.
} 


\section{Campaign execution}

The EUFAR (European Fleet for Airborne Research) program (http://www.eufar.net) provides scientists from European institutes with access to research aircraft. The first author of this paper was awarded 14 flight hours on the German Falcon research aircraft for a project called MEGAPLUME, for which we wanted to target a pollution plume from an American megacity over Europe. However, alternative targets were kept in mind from the beginning since the limited range of the aircraft, the short campaign duration of five days and the small number of flight hours dictated a plume-ofopportunity approach.

A major pollution plume from Asia was predicted by FLEXPART to arrive over Europe on 24-25 March 2006. In addition, pollution from North America was predicted in the vicinity of the Asian plume. The forecasts were not favorable for sampling a North American megacity plume, and so we decided to target the Asian plume and to also sample the adjacent pollution from North America. The Asian plume was forecasted to arrive over Europe late on 24 March and to have already passed over it on 25 March in the afternoon, thus leaving a rather short window of opportunity. The aircraft had to be back at its home base in Oberpfaffenhofen, southern Germany, on 24 March in the evening, and could be used on 25 March - a Saturday - only during the morning. Given these operational constraints, it was decided to fly a long mission on 24 March, with shuttle flights to and from Santiago in northwestern Spain, and a primary research flight (subsequently called flight A) as far out into the North Atlantic as possible. This flight was intended to characterize the Asian plume before eventual contamination by European sources and heavy aircraft traffic over the continent, as well as before the plume was leaving the zonal flow over the Atlantic and arriving at the rear of the trough over Central Europe, where there is often mixing with stratospheric air. On 25 March, a single flight from Oberpfaffenhofen to northeastern Spain and back (subsequently called flight B) was made.

Figure 1 shows the two flight tracks superimposed on maps of the total columns of the Asian CO tracer at about the time of the flights from the post-mission FLEXPART simulations. The 60-h forecast used for the flight planning was very similar. According to the model simulations, flight A reached the leading edge of the Asian pollution plume whereas flight $\mathrm{B}$ traversed the plume. Flight A suffered from limitations imposed by the Air Traffic Control. It was intended to fly a triangular pattern with one segment perpendicular to the plume orientation but this was not possible. Furthermore, the Falcon was not allowed to ascend higher than $9000 \mathrm{~m}$ since above this altitude it would have entered the air space of the organized flight routes of the transatlantic air traffic. Nevertheless, as will be shown next, both flights were successful. a) 24 March 2006, 12-15 UTC

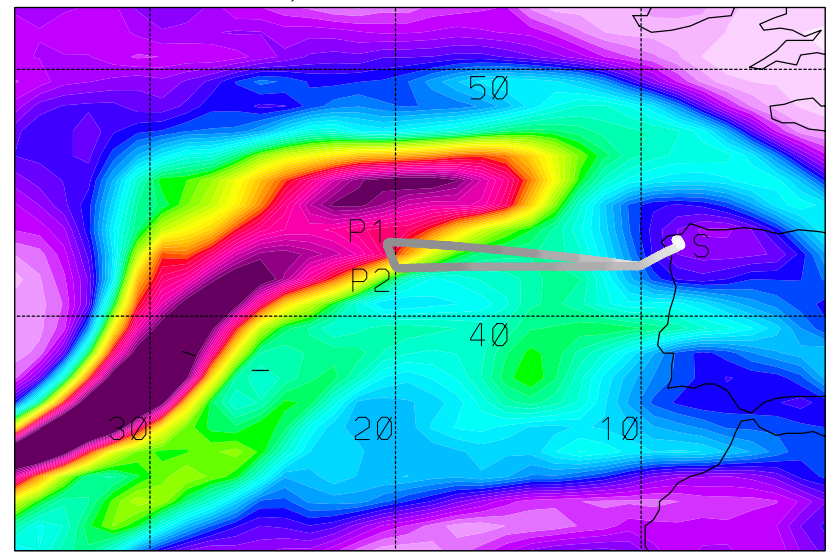

b) 25 March 2006, 9-12 UTC

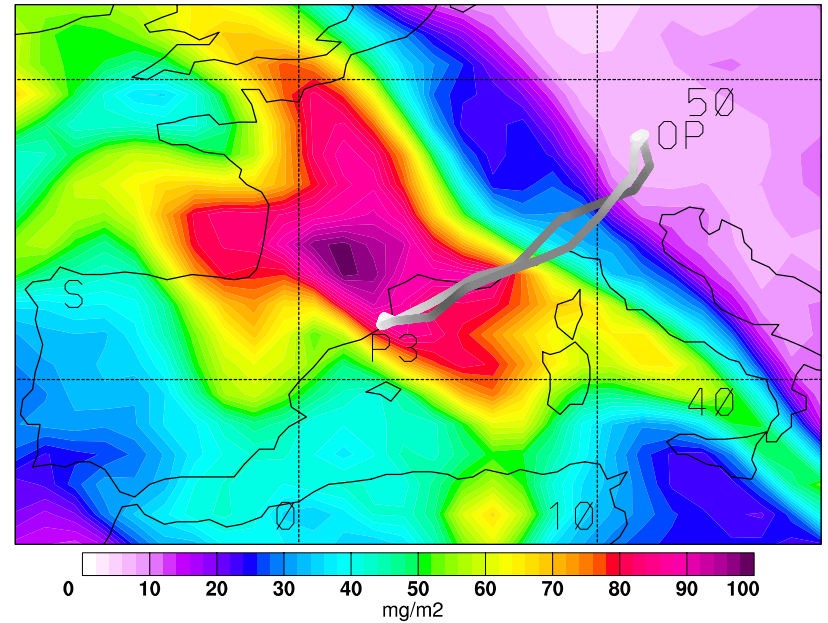

Fig. 1. Total columns of the Asian FFC CO tracer for (a) 24 March 2006 at 12:00-15:00 UTC and (b) 25 March 2006 at 09:0012:00 UTC. Superimposed are the tracks of flights A and B, respectively, with shading from white $(0 \mathrm{~m}$ asl $)$ to black $(13 \mathrm{~km}$ a.s.1.). The airports at Santiago (S) and Oberpfaffenhofen (OP) and way points (P1, P2 and P3) are marked.

\section{Results}

4.1 Meteorological conditions and transport from Asia to Europe

Figure 2 shows the transport history of the Asian pollution plume, as simulated forward in time with FLEXPART, and Fig. 3 shows corresponding maps of $\mathrm{CO}$ retrieved from the AIRS measurements for a reference altitude of $350 \mathrm{hPa}$. This altitude was chosen for the AIRS retrievals because most of the transport occurred in the upper troposphere where the Asian plume is also easier to distinguish from other lowlevel plumes. Between 10 and 17 March (not shown), the air mass arriving over Europe on 24-25 March had travelled from India to China at low altitudes, taking up copious amounts of emissions en route. The plume had left the east 
(a)

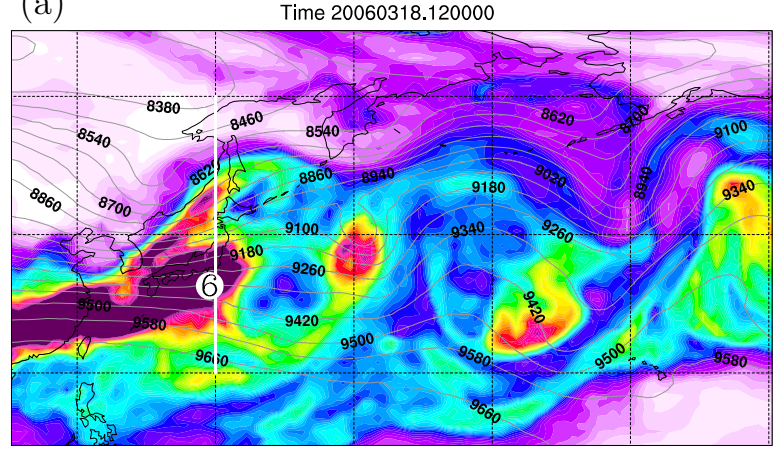

(b)

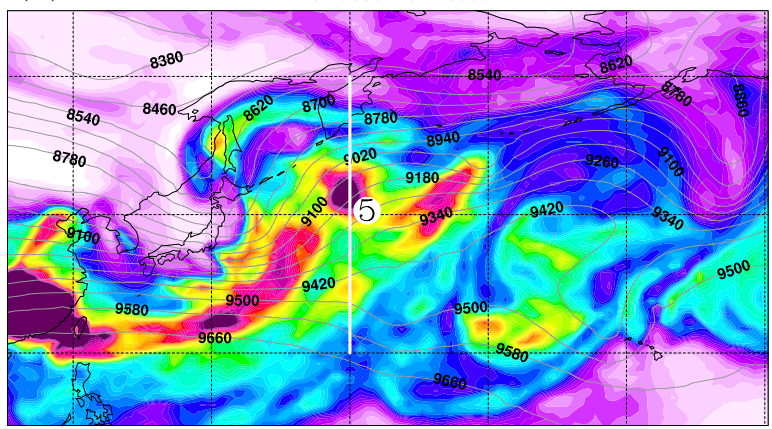

(c)

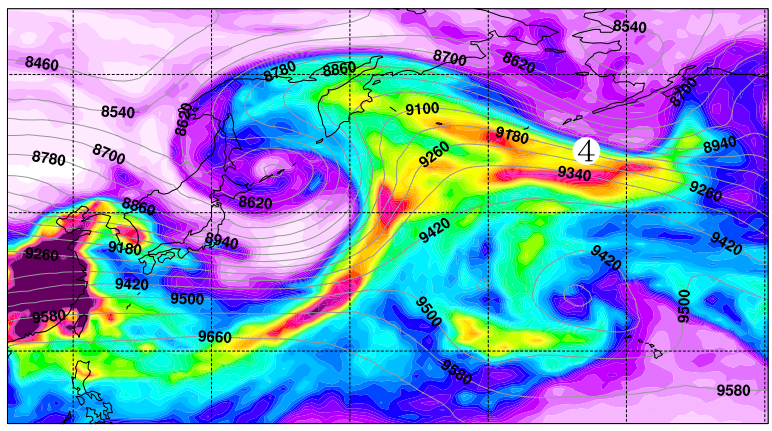

(d)

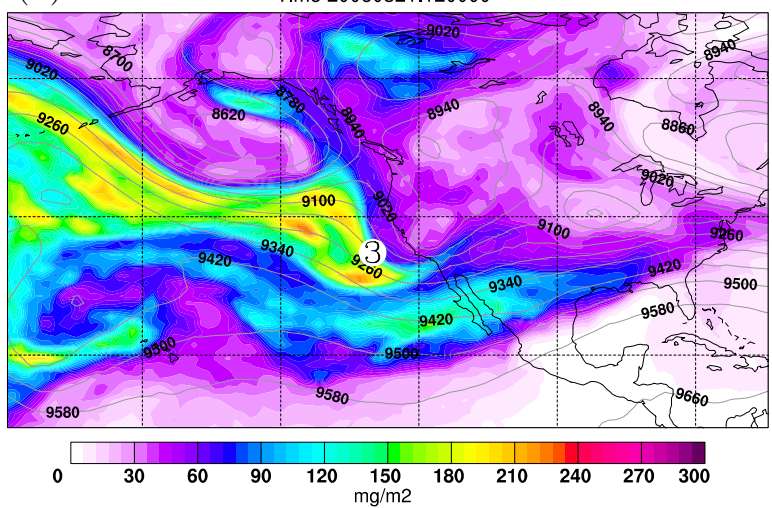

(e)

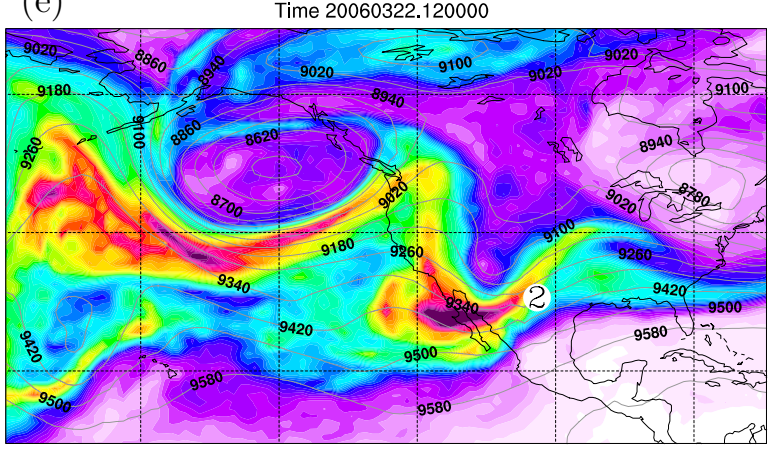

(f)

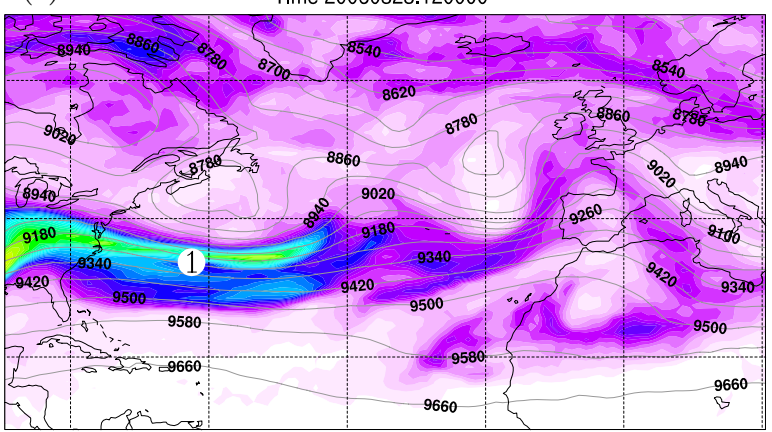

$(\mathrm{g})$

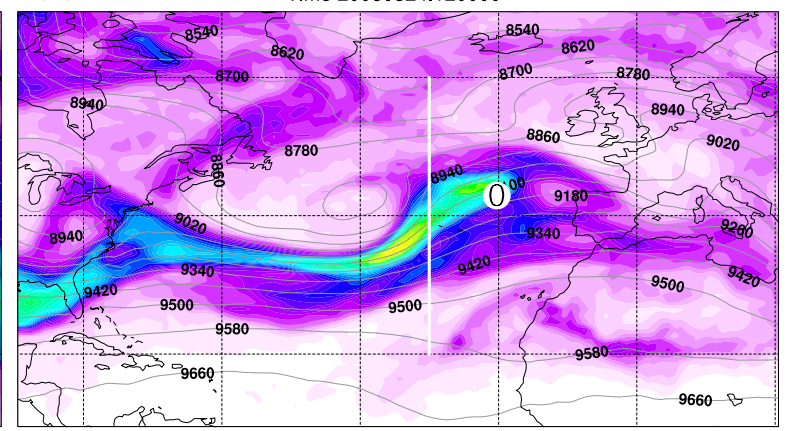

(h)

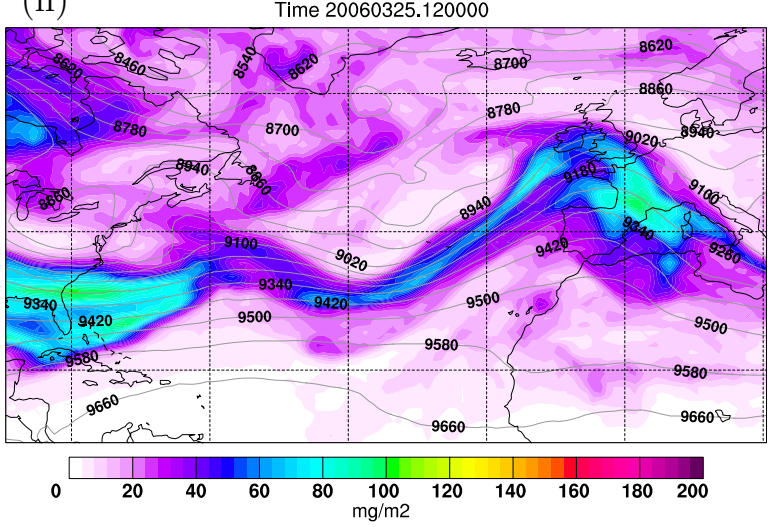

Fig. 2. Total columns of the Asian CO tracer at 12:00 UTC on (a) 18 March, (b) 19 March, (c) 20 March, (d) 21 March, (e) 22 March, (f) $23 \mathrm{March}$, (g) $24 \mathrm{March}$, and (h) $25 \mathrm{March}$. Note the different color scales in the left and right panels. Overlayed with labeled gray contours is the geopotential height $[\mathrm{m}]$ at $300 \mathrm{hPa}$. The regions shown are $10-70^{\circ} \mathrm{N}$ for all plots and $110^{\circ} \mathrm{E}-140^{\circ} \mathrm{W}$ for panels $(\mathrm{a}-\mathrm{c}), 180-70^{\circ} \mathrm{W}$ for panels (d-e), and $90^{\circ} \mathrm{W}-20^{\circ} \mathrm{E}$ for panels (f-h). White circles (superimposed numbers give the days back in time) mark the retroplume centroid positions of the FLEXPART backward calculation from the measured plume maximum on 24 March (see Fig. 8). 
(a)

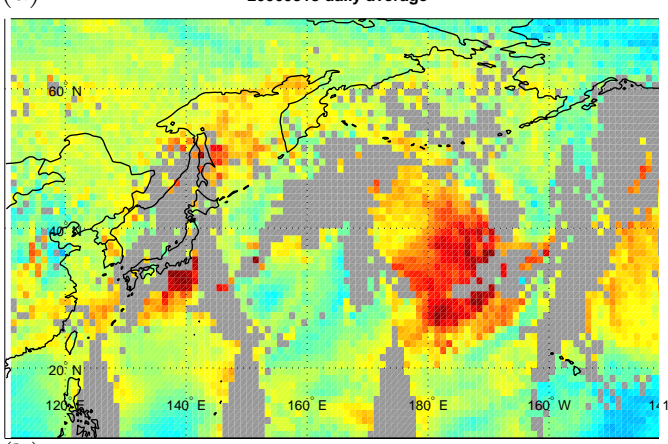

(b)

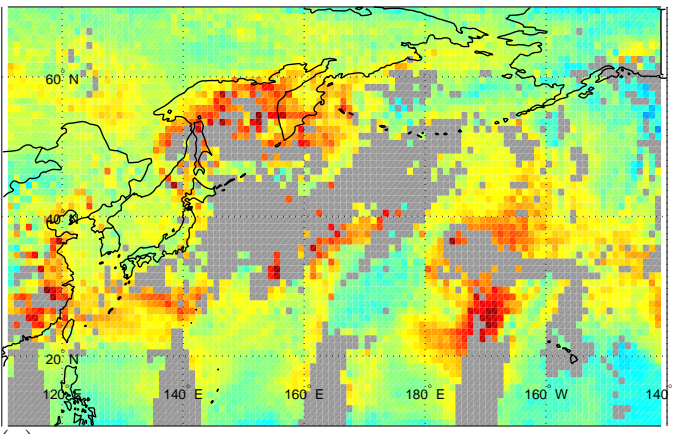

(c)

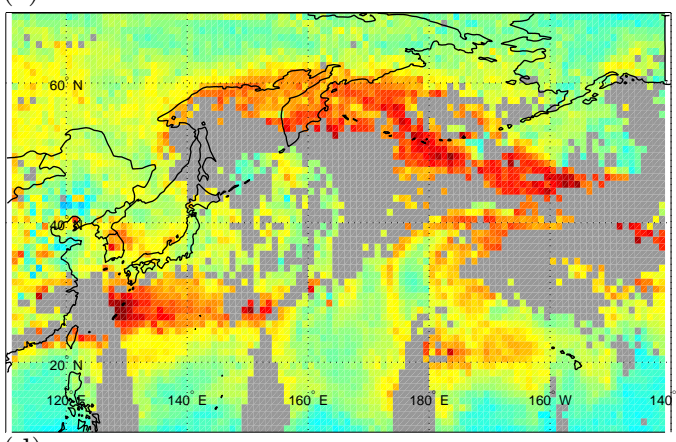

(d)

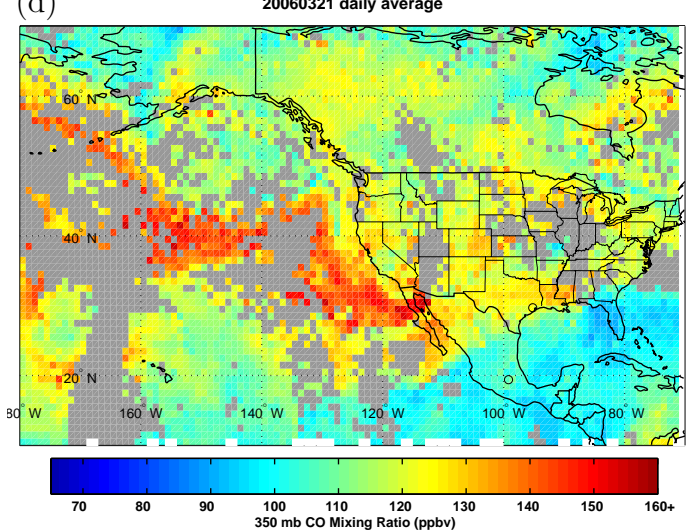

(e)

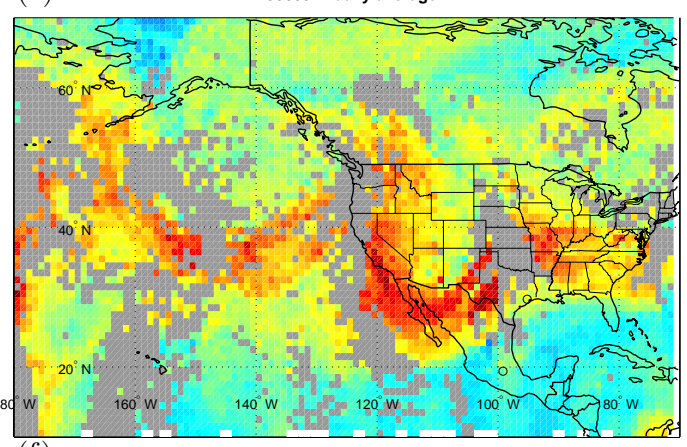

(f)

20060323 daily average

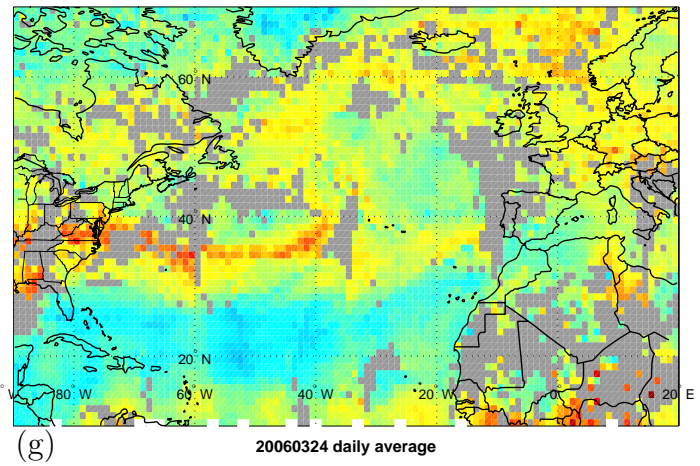

(g)

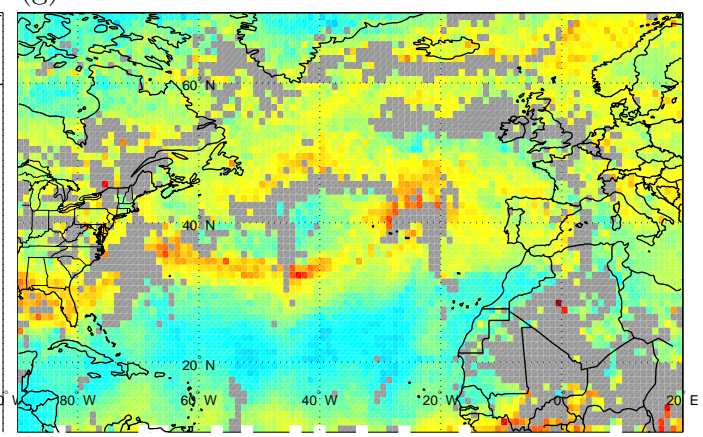

(h)

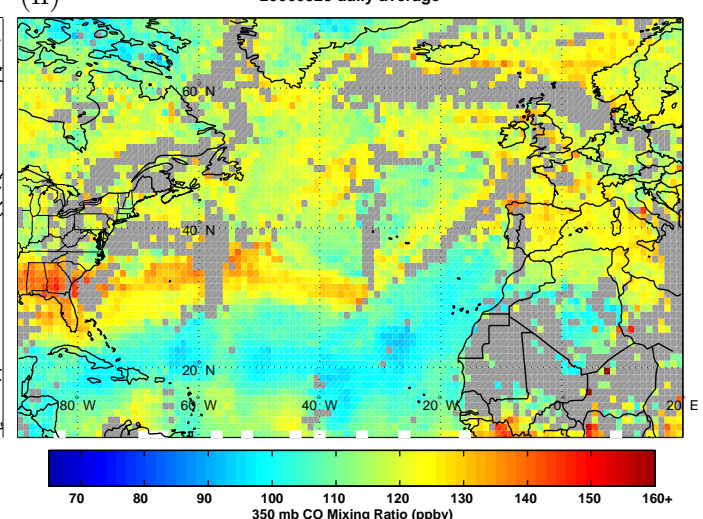

Fig. 3. CO retrieved for a reference altitude of $350 \mathrm{hPa}$ from daily AIRS measurements for (a) $18 \mathrm{March}$, (b) $19 \mathrm{March}$, (c) $20 \mathrm{March}$, (d) 21 March, (e) 22 March, (f) 23 March, (g) 24 March, and (h) 25 March. The regions shown are identical to those in Fig. 2. Grey areas mark regions without data coverage or where retrievals were not successful due to cloud obscuration. 


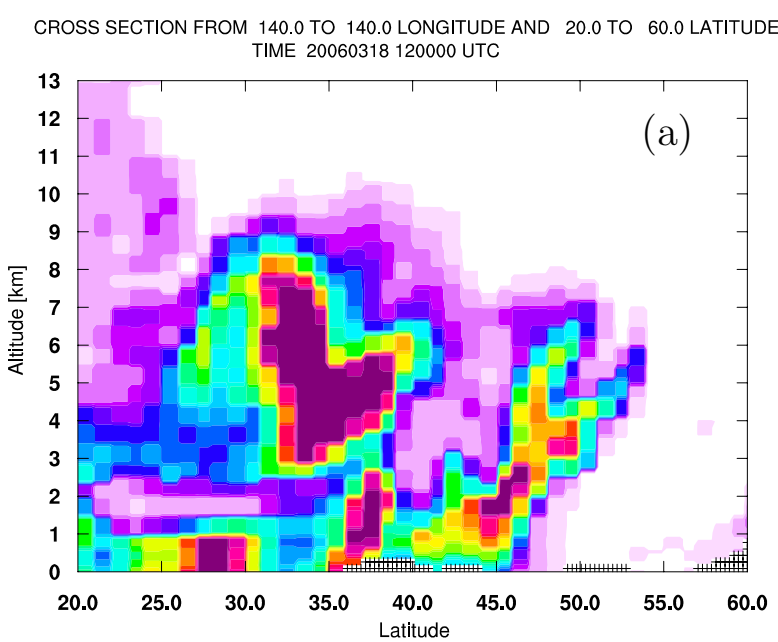

CROSS SECTION FROM 160.0 TO 160.0 LONGITUDE AND 20.0 TO 60.0 LATITUDE TIME 20060319120000 UTC

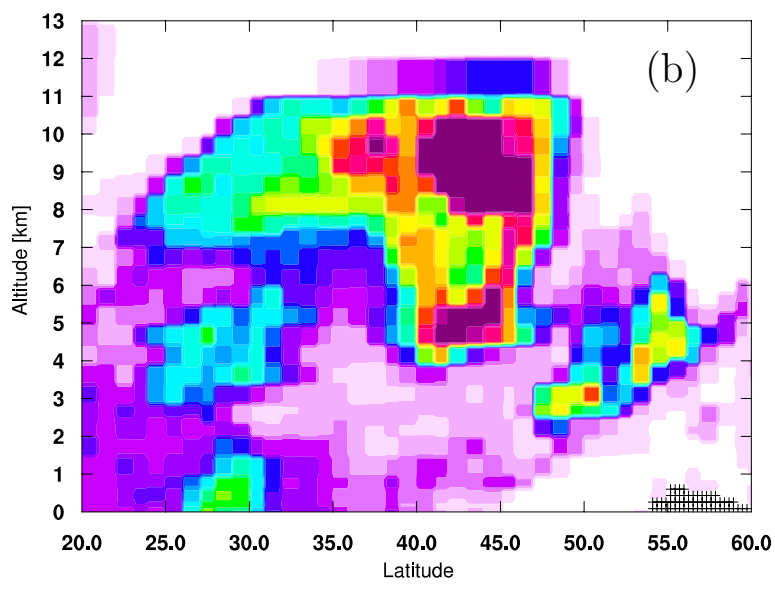

CROSS SECTION FROM -30.0 TO -30.0 LONGITUDE AND 20.0 TO 60.0 LATITUDE

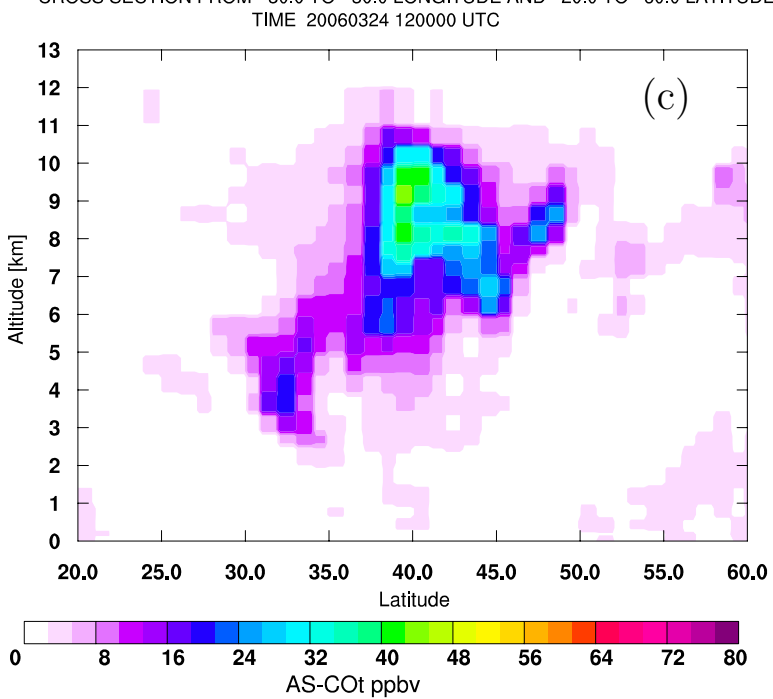

Fig. 4. Vertical cross sections of the Asian $\mathrm{CO}$ tracer [ppbv] (a) at $140^{\circ} \mathrm{E}$ on $18 \mathrm{March},(\mathbf{b})$ at $160^{\circ} \mathrm{E}$ on $19 \mathrm{March}$, and (c) at $30^{\circ} \mathrm{W}$ on 24 March, all at 12:00 UTC. The positions of the vertical sections are shown as white lines in the corresponding panels of Fig. 2. coast of China at levels below $3 \mathrm{~km}$ on 17 March and was located between $30^{\circ}$ and $40^{\circ} \mathrm{N}$ over and southeast of Japan on 18 March (Fig. 2a). The white circle in Fig. 2a labels the position of the observed plume maximum, projected backward in time (for explanation, see later) to the date shown, to identify the part of the plume sampled later by the Falcon. A trough and its associated cold front were approaching from the northwest and started to lift the leading part of the plume to levels between 3 and $8 \mathrm{~km}$ altitude (Fig. 4a). The CO retrieved from AIRS shows a maximum above $160 \mathrm{ppb}$ to the east of southern Japan and confirms the export of pollution from Asia (Fig. 3a). However, clouds obscured large parts of the plume from satellite detection, and the trailing part of the plume was still well below the $350 \mathrm{hPa}$ reference height on 18 March.

One day later, on 19 March, the trough had intensified and almost passed Japan (Fig. 2b). At this time the plume was located entirely in the cyclone's WCB, and its leading part - the part finally sampled over Europe - was already in the upper troposphere (Fig. 4b) where it moved northeast-, then east- and southeastwards in a rapid upper tropospheric air stream on the following two days (Fig. 2c and 2d). It looks as if the plume merged with a second plume that was located at $160^{\circ} \mathrm{E}$ on 18 March (Fig. 2a) and that was travelling into the same direction on 19 and 20 March. However, this second plume moved at low levels and much slower than the one of interest here and was quickly overtaken by it. The AIRS retrievals for 19 March suffered from the cloudiness in the WCB and only hint at a major pollution outflow event (Fig. 3b) but on 20 (Fig. 3c) and 21 March (Fig. 3d), the plume was fully exposed to the satellite measurements and confirms the transport of the plume across the North Pacific. AIRS-retrieved CO mixing ratios are larger than $150 \mathrm{ppbv}$ in a pollution stream extending over more than $5000 \mathrm{~km}$.

On $21 \mathrm{March}$, the upper tropospheric plume already approached the Californian coast (Fig. 2d and Fig. 3d). While a part of the plume descended to mid-tropospheric levels and moved southeastward behind the trough over the Californian coast, another part stayed in the upper troposphere, traveled rapidly around the trough and crossed the central U.S. on 22 March (Fig. 2e and Fig. 3e). Then it got into a strong, nearly zonal flow along about $35^{\circ} \mathrm{N}$ (Fig. 2f) and crossed the North Atlantic within 2 days (Fig. $2 \mathrm{~g}$ and $2 \mathrm{~h}$; Fig. $3 \mathrm{~g}$ and Fig. 3h), still moving at upper tropospheric levels (Fig. 4c). In total, the journey from the east coast of Asia to the west coast of Europe took only 7 days. Finally, on 25 March the plume arrived over western France (Fig. $2 \mathrm{~h}$ and Fig. 3h) behind a trough that had been located west of Spain on 23 March (Fig. 2f) and had traversed Spain between 23 and 24 March (Fig. 2g). Even over Europe on 25 March (Fig. 3h), the Asian CO plume can still be clearly identified in the AIRS CO retrievals. Additional features in the AIRS map over major European population centers must actually come from lower levels in the troposphere and are the result of the broad averaging kernel used in the AIRS retrieval. 

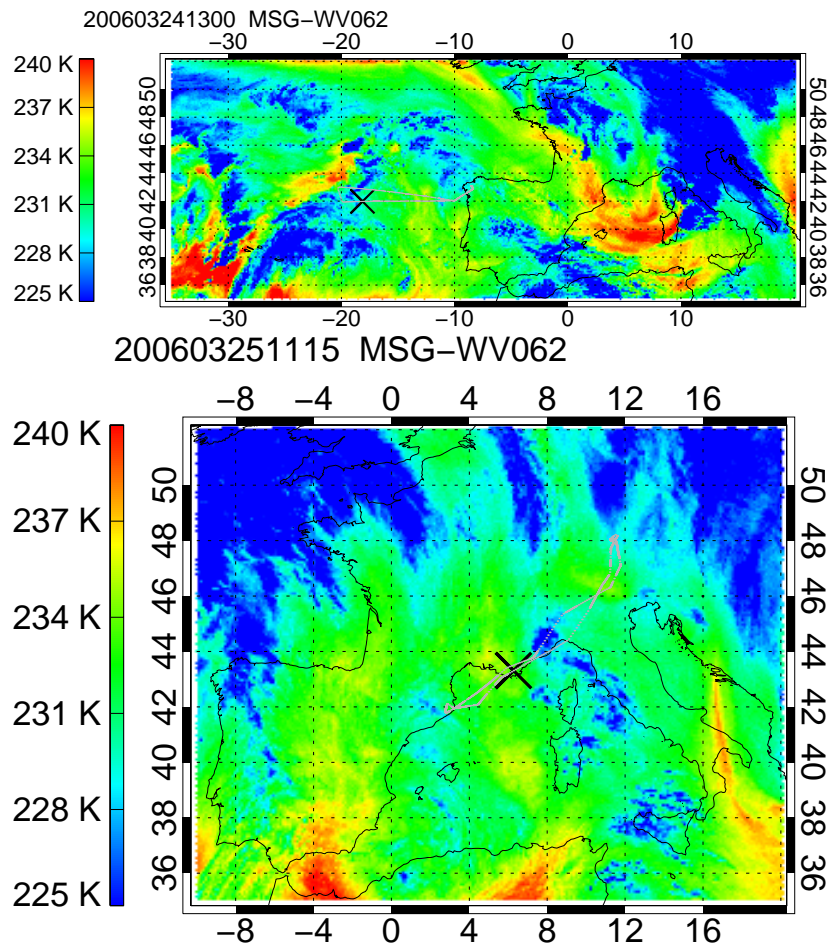

Fig. 5. Equivalent blackbody temperature of the METEOSAT-8 WV_062 channel centered in the water vapor absorption band on 24 March at 13:00 UTC (top) and on 25 March at 11:15 UTC (bottom). The routes of flight A and B are superimposed as grey lines, and the position of the aircraft at the time of the image is marked by a cross.

Overall, the comparison between the FLEXPART simulation and the AIRS retrievals shows excellent agreement over the entire transport history, indicating a very high accuracy of the simulated transport.

Polluted air masses from North America were located below the Asian plume in the mid-troposphere. These North American air masses had left the East coast of the U.S. on 21 March and arrived over Spain and France at about the same time as the Asian plume but at lower altitudes. In the AIRS retrievals for 23 March (Fig. 3f), this North American plume can be seen east of about $40^{\circ} \mathrm{W}$, ahead of the Asian plume, with lower mixing ratios than measured in the Asian plume.

Figure 5 shows the equivalent blackbody temperature of the METEOSAT-8 WV_062 channel centered in the water vapor absorption band, for the times of flights $\mathrm{A}$ and $\mathrm{B}$. In a cloud-free mid-latitude standard atmosphere the dominating part of the signal results from approximately $300 \mathrm{hPa}$. If the air is dry, lower and thus warmer layers contribute to the signal. The ice particles of cirrus clouds emit with their own temperature and show up as cold, structured areas. On 24 March, the Asian plume (Fig 1) was co-located with a dry upper tropospheric air mass (Fig. 5, top), with the predicted plume shape being similar to that of the dry region. a) 24 March 2006

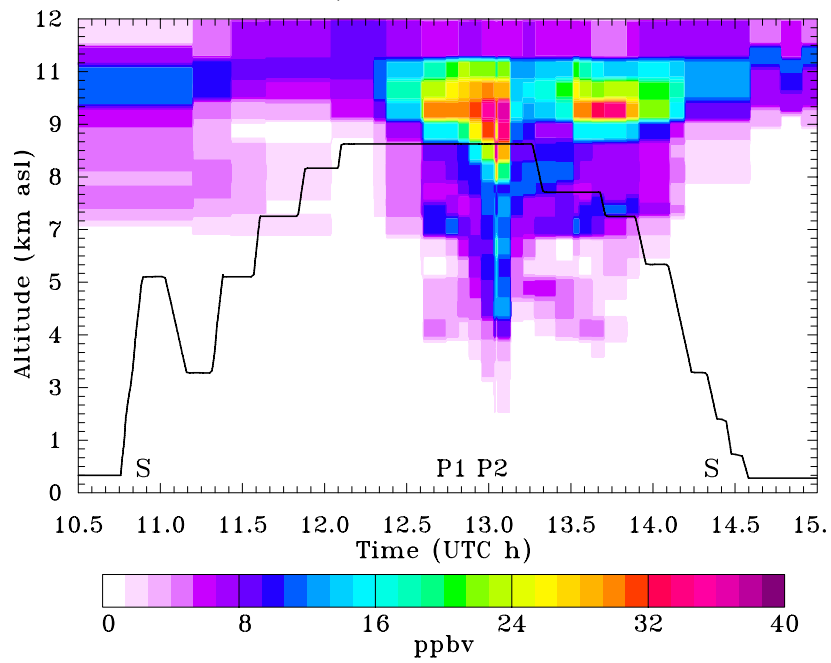

b) 25 March 2006

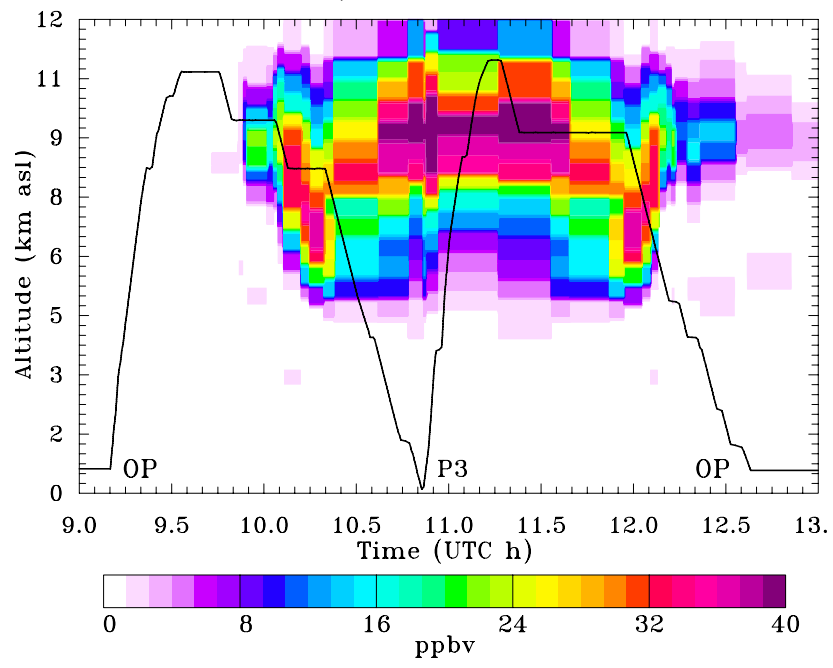

Fig. 6. Time-height curtains through the Asian FFC CO tracer along the tracks of (a) flight A on 24 March 2006, and (b) flight B on 25 March 2006. The black line shows the flight altitude. Times of ascents/descents from/to airports in Santiago (S) and Oberpfaffenhofen (OP) and arrivals at way points (P1, P2 and P3) are marked.

However, the measurements were made in the leading part of the plume where cirrus cloud fields were present. Over southwestern France and the Mediterranean $\left(0-10^{\circ}\right.$ E, about $40^{\circ} \mathrm{N}$ ), the air was very dry on 24 March, indicating the descent of stratospheric air into the troposphere on the rear of the trough (compare with Fig. 2g). The stratospheric intrusion related to this trough was encountered by flight $\mathrm{B}$ on the next day near the region with the warm temperatures seen in Fig. 5 (bottom) just to the west of the aircraft position marked with a cross. As we shall see, on 25 March, some of the Asian pollution was located between the stratosphere above and the stratospheric intrusion below and was mixing with both of them. 


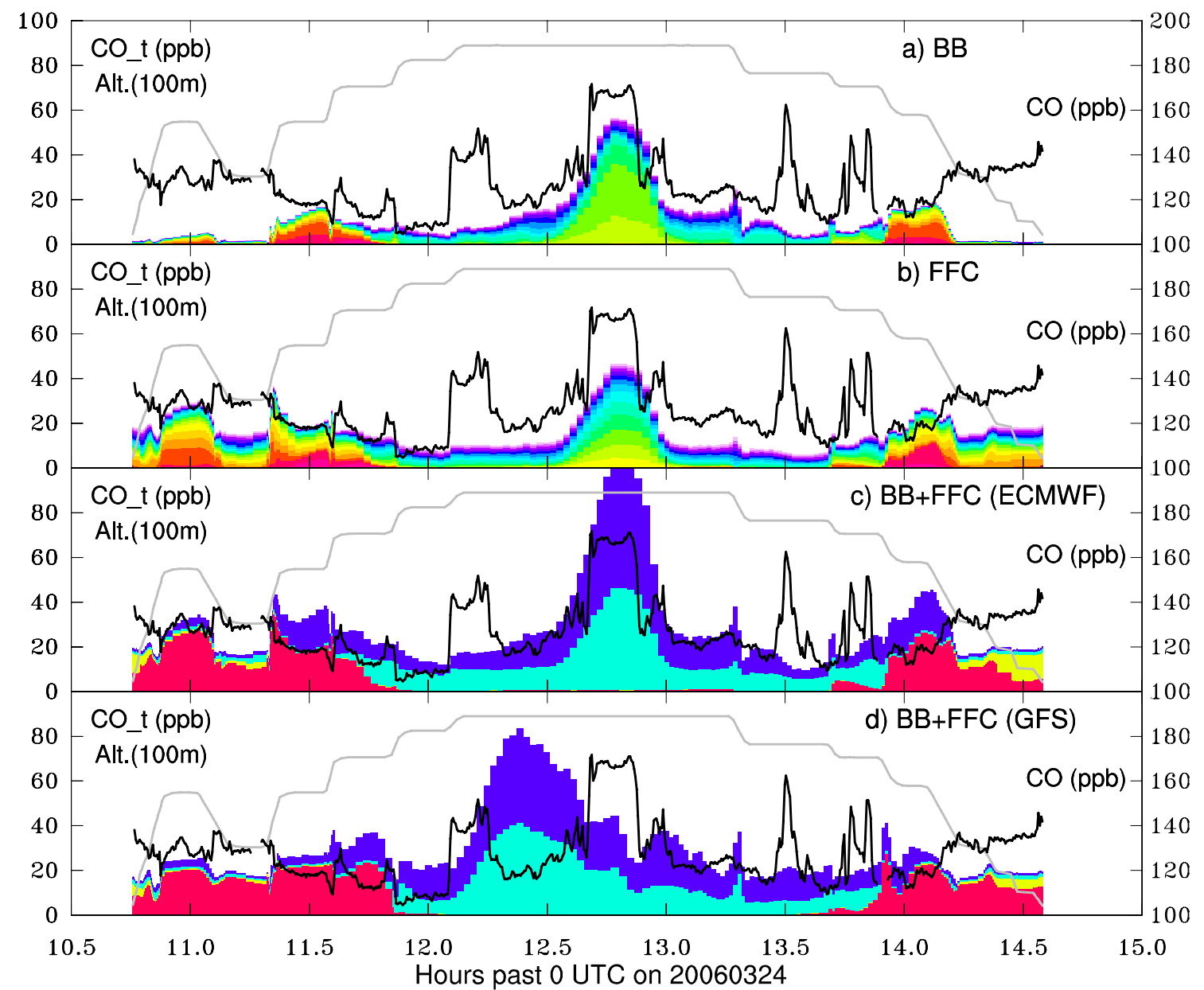

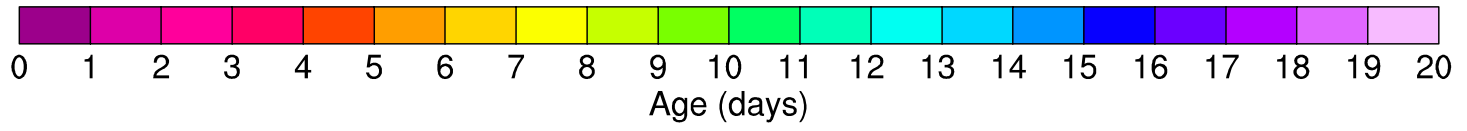

\begin{tabular}{|l|l|l|}
\hline & & \\
FFC N. America & FFC Europe & FFC Asia
\end{tabular}

Fig. 7. Comparison of time series of modeled CO tracers from the backward simulations (colored bars, left axes) with measured CO (black lines, right axes) for flight A on 24 March 2006. Note that the axes are labelled inside the figure, with "CO_t" corresponding to the modeled $\mathrm{CO}$ tracer and "CO" corresponding to the measured CO. Measured CO is shown in every panel, whereas the colored bars are (a) BB CO tracer, (b) sum of all three regional FFC CO tracers, (c) BB+FFC CO tracer, (d) BB+FFC CO tracer. Model results shown in panels (a-c) were produced by driving FLEXPART with ECMWF analyses, and those shown in panel (d) were produced using GFS data. The colors in a) and b) give the age (i.e., time since emission) of the CO tracers according to the top label bar, whereas in (c) and (d) the colors separate regional FFC tracers and BB according to the bottom label bar. The grey line shows the flight altitude.

4.2 Identification of flight segments influenced by the Asian pollution

\subsubsection{Flight A}

Figure 6 shows the mixing ratios of the Asian $\mathrm{CO}$ tracer obtained from the forward model simulation interpolated onto curtains along the flight tracks. According to the model results, the aircraft encountered the Asian plume in the middle section (i.e., farthest to the west) of flight A (Fig. 6a). The simulated plume was located mainly between 8 and $11 \mathrm{~km}$ and was underflown most of the time. Nevertheless, as we will see later, the Asian plume was sampled several times, in the general region where the model places it, albeit at too high altitudes.

Figure 7 shows regional $\mathrm{CO}$ tracer mixing ratios obtained from the series of backward simulations along flight $\mathrm{A}$. FLEXPART, based on the ECWMF data (Fig. 7c), predicts a single strong encounter of the Asian FFC plume (shown in blue) between 12:30 and 13:00 UTC but weaker "Asian 
a) Column-integrated potential emission sensitivity

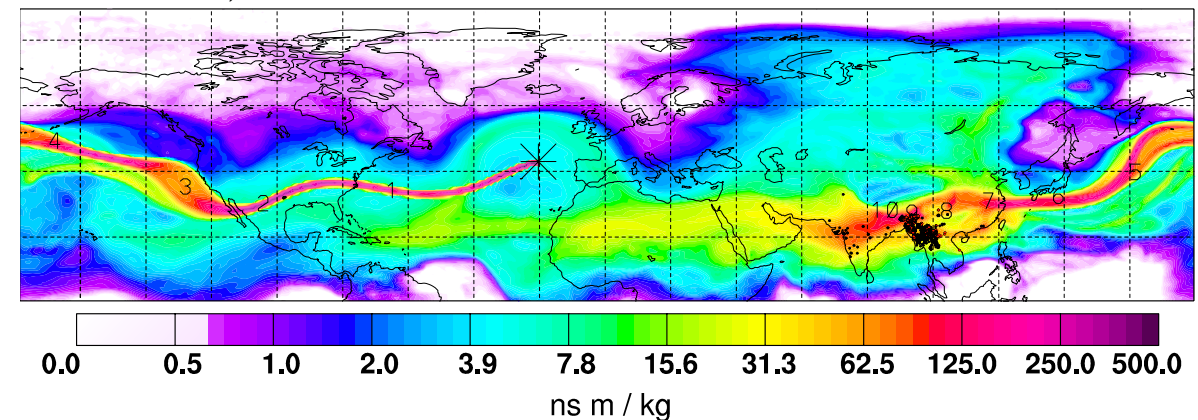

b) Footprint potential emission sensitivity

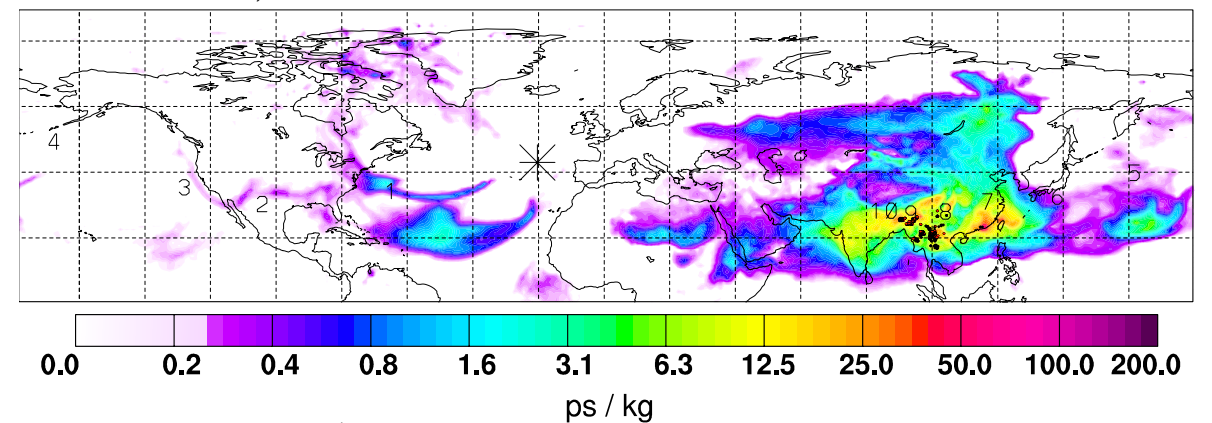

c) $\mathrm{CO}$ potential source contribution

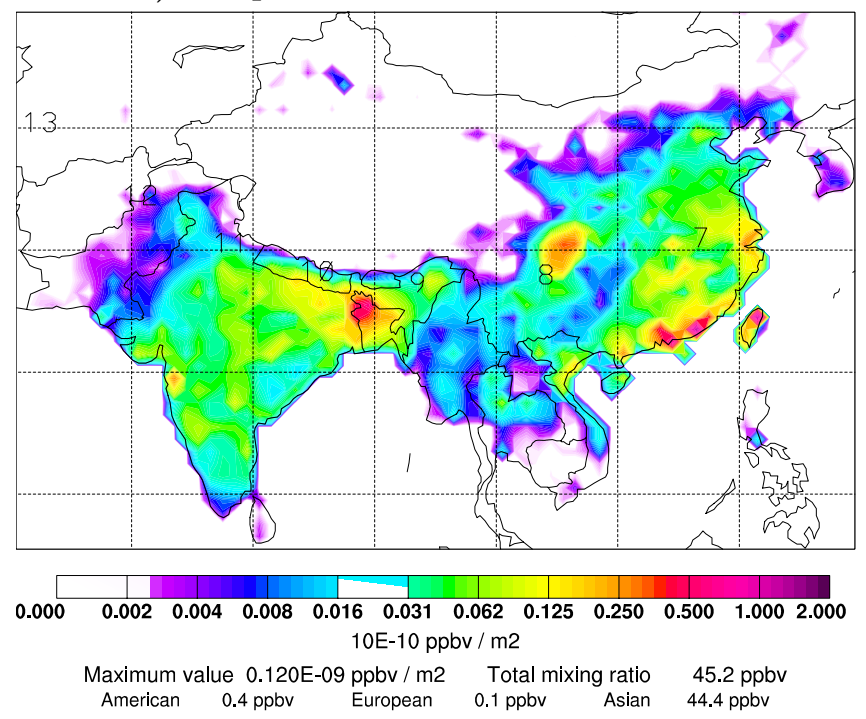

Fig. 8. Retroplume results from the backward simulation for the segment from 12:46-12:48 UTC (altitude of $315 \mathrm{hPa}$ ) of flight A on 24 March 2006. Shown are (a) the column integrated PES, (b) the footprint PES, and (c) the PSC for FFC CO over Southeastern Asia. The numbers on the plots give the daily retroplume centroid positions (only up to 10 days back in panels a and b), the aircraft position is shown by an asterisk at about $20^{\circ} \mathrm{W}$. Black dots in panels (a) and (b) show MODIS fire detections on days when the column-integrated PES (footprint PES) in the corresponding grid cell on that day exceeded $8 \mathrm{~ns} \mathrm{~m} \mathrm{~kg}{ }^{-1}\left(5 \mathrm{ps} \mathrm{kg}^{-1}\right)$. If a fire detection occurred in a pixel with forest as the main land cover type, a smaller red dot is superimposed.

influence" along most of the flight. The FLEXPART results using the alternative GFS input data (Fig. 7d) are similar but suggest the plume maximum earlier along the flight track. Both model versions predict North American FFC CO tracer (shown in red in Fig. 7c and 7d) for the first and last hour of the flight.
The age (i.e., time since emission) of the North American pollution (Fig. 7b) is less than a week, whereas the Asian plume is between 7 and 15 days old, with smaller contributions up to the maximum simulated age of 20 days. The minimum age marks the time when the plume left the Asian seaboard, on 17 March. FLEXPART also suggests that BB 


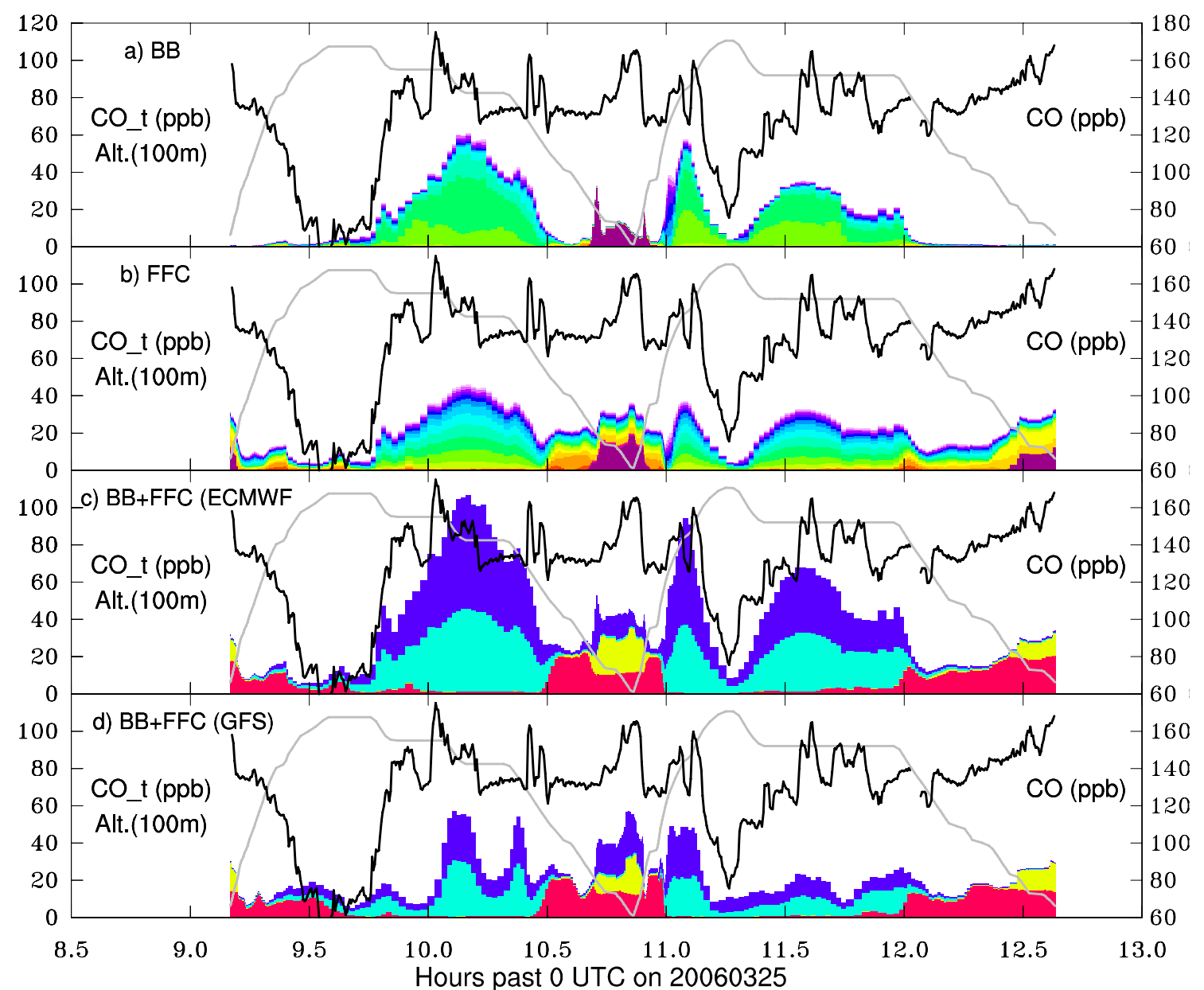

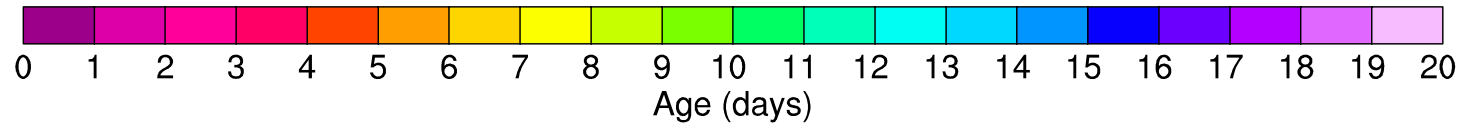

FFC N. America

FFC Europe

FFC Asia

BB

Fig. 9. Same as Fig. 7 but for flight B on 25 March 2006.

contributed slightly more $\mathrm{CO}$ to the Asian plume (Fig. 7a) than FFC (Fig. 7b), but this result is highly uncertain due to the lack of information on the actual areas burned. We shall see later that the actual BB contribution was probably smaller.

Figure 7 also shows the measured $\mathrm{CO}$ mixing ratios along the flight track. They show considerably more variability than the model results and four maxima in the general region of the Asian plume (from 12:00-14:00 UTC). The biggest maximum occurred at exactly the same time as simulated using the ECMWF data but the other maxima are not captured by the model simulations. As shown in the curtain plots (Fig. 6), the model placed the Asian plume above the flight track. For instance, the measured $\mathrm{CO}$ peaks from about 13:30-14:00 UTC are $2 \mathrm{~km}$ underneath a simulated plume maximum. Given that the measurements were all made close to the leading edge of the Asian plume, in a region with very strong concentration gradients (see Fig. 1), the partial disagreement between the model and the measurements is not surprising. In agreement with the measurements, the model predicts the lowest CO concentrations at 12:00 UTC, between the Asian plume and the moderately strong North American plume. The simulated maximum CO tracer mixing ratios of the combined FFC and BB emissions (Fig. 7c) slightly overpredict the observed $\mathrm{CO}$ enhancements in the Asian plume, probably because of an overestimate of the BB emissions.

Figure 8 shows the retroplume results from the ECMWF backward simulation for the period from 12:46-12:48 UTC, which yielded the highest Asian FFC CO tracer mixing 


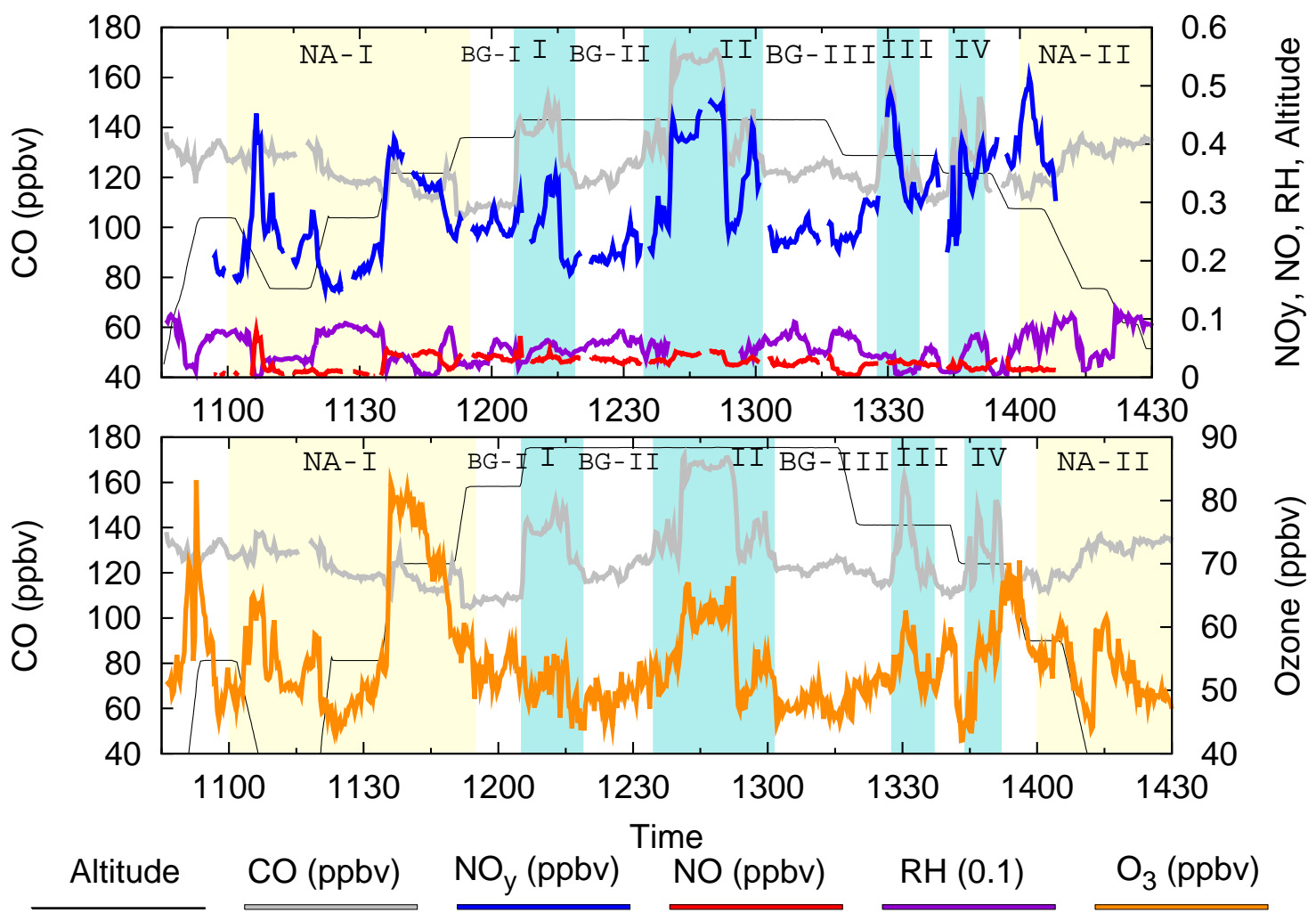

Fig. 10. Time series of $\mathrm{CO}, \mathrm{NO}, \mathrm{NO}_{\mathrm{y}}, \mathrm{O}_{3}$ and $\mathrm{RH}$ over liquid water measured during flight $\mathrm{A}$ on 24 March 2006. Flight altitudes are shown in relative units. The time series were smoothed by calculating 20 -s running means from the original 1-s data. Periods with encounters of North American pollution are marked with yellow background and are labelled NA-I and NA-II. Four penetrations of the Asian plume are highlighted with turquoise background and are labelled I-IV. Three "background" periods are labelled BG-I, BG-II and BG-III.

ratio. The PES integrated over the entire atmospheric column (Fig. 8a) illustrates the pathway of the polluted air mass. The retroplume was well confined (i.e., almost followed a single trajectory) for 6 days back, as the transport occurred in the upper troposphere in a narrow latitude band from $30-50^{\circ} \mathrm{N}$. The retroplume centroid positions are marked at daily intervals, and these markers were also shown in the plots of the forward tracer simulation (Fig. 2). The Asian seaboard was reached 7 days back when the retroplume touched down into the PBL and spread considerably further back in time, due to boundary layer turbulence.

The footprint PES plot (Fig. 8b) shows almost no signal before the retroplume reached Asia as the transport from Asia occurred in the upper troposphere (most of the weak signals over the North Atlantic and North Pacific are older than 6 days). Only after the retroplume descended in the WCB (backward in time) into the Southeast Asian PBL, high footprint emission sensitivity values can be found over China, India and other countries in Southeast Asia. Also shown in Fig. 8 are the locations of active fires detected on days when the retroplume passed over them and produced a minimum PES of $5 \mathrm{ps} \mathrm{kg}^{-1}$ in the footprint layer (Fig. 8b) or a minimum column-integrated PES of $8 \mathrm{~ns} \mathrm{~m} \mathrm{~kg}^{-1}$ (Fig. 8a). These threshold values were chosen subjectively in order to show fires only where they would produce a noticeable PSC, given typical estimated fire emission strengths. Most of the fires were detected on agricultural lands in Myanmar and Thailand. The size of these fires is not known and, thus, the emission strength is highly uncertain. However, the Asian pollution plume likely contained a mixture of FFC and BB emissions, which is typical for pollution outflow from Southeast Asia (Russo et al., 2003). Figure 8c, the PSC map resulting from the folding of the footprint PES map with the FFC emission inventory, suggests that FFC emissions from a vast region contributed to the pollution plume. The retroplumes started from other flight segments in the simulated Asian plume (also those using the alternative GFS data) showed almost the same source region and a very similar transport route but lower footprint PES (and, thus, smaller PSC) values.

\subsubsection{Flight B}

During flight B on 25 March, the aircraft travelled from southern Germany to northeastern Spain, where it descended to near the surface, ascended to the maximum altitude of 
Table 2. Mean and excess trace gas mixing ratios during the periods NA-I, NA-II, background periods BG-I, BG-II and BG-III, and Asian plume encounters I-IV of flight A as defined in Fig. 10, and during the Asian plume encounters I-V, as well as periods S-I, S-II and BL as defined in Fig. 12.

\begin{tabular}{|c|c|c|c|c|c|c|c|c|}
\hline Flight & Period & $\begin{array}{l}\text { Mean } \\
\mathrm{CO}, \\
\text { ppbv }\end{array}$ & $\begin{array}{l}\text { Excess } \\
\mathrm{CO}, \\
\text { ppbv }\end{array}$ & $\begin{array}{l}\text { Mean } \\
\mathrm{O}_{3}, \\
\text { ppbv }\end{array}$ & $\begin{array}{l}\text { Excess } \\
\mathrm{O}_{3} \\
\text { ppbv }\end{array}$ & $\begin{array}{l}\text { Mean } \\
\text { NO, } \\
\text { pptv }\end{array}$ & $\begin{array}{l}\text { Mean } \\
\mathrm{NO}_{\mathrm{y}}, \\
\text { ppbv }\end{array}$ & $\begin{array}{l}\text { Mean } \\
\mathrm{NO} / \mathrm{NO}_{\mathrm{y}} \\
\text { ratio }\end{array}$ \\
\hline \multirow[t]{9}{*}{ A } & NA I+II & 124 & 9 & 56 & 8 & 17 & 0.28 & 0.07 \\
\hline & BG-I & 108 & -7 & 53 & 5 & 34 & 0.26 & 0.13 \\
\hline & BG-II & 121 & 6 & 49 & 1 & 30 & 0.21 & 0.14 \\
\hline & BG-III & 121 & 6 & 48 & 0 & 20 & 0.25 & 0.08 \\
\hline & I & 137 & 22 & 50 & 2 & 33 & 0.26 & 0.12 \\
\hline & II & 149 & 34 & 57 & 9 & 33 & 0.36 & 0.09 \\
\hline & III & 132 & 17 & 55 & 7 & 25 & 0.36 & 0.07 \\
\hline & IV & 133 & 18 & 55 & 7 & 17 & 0.34 & 0.05 \\
\hline & I-IV mean & 138 & 23 & 54 & 6 & 27 & 0.33 & 0.08 \\
\hline \multirow[t]{8}{*}{ B } & I & 144 & 9 & 66 & 16 & 56 & 0.57 & 0.10 \\
\hline & II & 152 & 17 & 61 & 11 & 43 & 0.52 & 0.08 \\
\hline & III & 146 & 11 & 59 & 9 & 11 & 0.43 & 0.03 \\
\hline & IV & 142 & 7 & 74 & 24 & 50 & 0.58 & 0.09 \\
\hline & $\mathrm{V}$ & 145 & 10 & 65 & 15 & 87 & 0.53 & 0.16 \\
\hline & S-I & 88 & - & 169 & - & 162 & 1.16 & 0.14 \\
\hline & S-II & 92 & - & 159 & - & 204 & 1.00 & 0.20 \\
\hline & $\mathrm{BL}$ & 150 & - & 47 & - & 816 & 3.87 & 0.21 \\
\hline
\end{tabular}

Table 3. Trace gas correlations during the periods NA-I, NA-II, and Asian plume encounters I-IV of flight A as defined in Fig. 10, and during the Asian plume encounters I-V, as well as periods S-I, S-II and BL as defined in Fig. 12. Squared correlation coefficients $\left(\mathrm{r}^{2}\right)$ and slopes of the regression lines are reported.

\begin{tabular}{cccccccc}
\hline Flight & Period & $\Delta \mathrm{NO}_{\mathrm{y}} / \Delta \mathrm{CO}$ & $\mathrm{r}^{2}$ & $\Delta \mathrm{O}_{3} / \Delta \mathrm{CO}$ & $\mathrm{r}^{2}$ & $\Delta \mathrm{O}_{3} / \Delta \mathrm{NO}_{\mathrm{y}}$ & $\mathrm{r}^{2}$ \\
\hline A & NA I+II & $-2.31 \times 10^{-3}$ & 0.03 & -0.39 & 0.11 & 66.7 & 0.37 \\
& I & $4.87 \times 10^{-3}$ & 0.24 & 0.31 & 0.73 & 44.9 & 0.38 \\
& II & $4.13 \times 10^{-3}$ & 0.78 & 0.30 & 0.75 & 61.3 & 0.67 \\
& III & $4.32 \times 10^{-3}$ & 0.98 & 0.24 & 0.75 & 56.3 & 0.79 \\
& IV & $4.15 \times 10^{-3}$ & 0.79 & 0.22 & 0.22 & 76.8 & 0.59 \\
\hline & I-IV mean & $4.49 \times 10^{-3}$ & & 0.25 & & 59.8 & \\
B & & & & & & & \\
& I & $-0.73 \times 10^{-3}$ & 0.01 & -0.35 & 0.17 & 61.8 & 0.27 \\
& II & $5.69 \times 10^{-3}$ & 0.37 & 0.07 & 0.02 & 45.3 & 0.64 \\
& III & $\mathbf{4 . 4 0 \times 1 0 ^ { - 3 }}$ & $\mathbf{0 . 9 7}$ & $\mathbf{0 . 2 3}$ & $\mathbf{0 . 4 2}$ & $\mathbf{5 3 . 7}$ & $\mathbf{0 . 5 3}$ \\
& IV & $1.88 \times 10^{-3}$ & 0.09 & -0.62 & 0.21 & 181.6 & 0.61 \\
& V & $1.01 \times 10^{-3}$ & 0.01 & -0.25 & 0.18 & 5.4 & 0.01 \\
& S-I & $-9.6 \times 10^{-3}$ & 0.74 & -2.70 & 0.94 & 210.2 & 0.69 \\
& S-II & $-12.5 \times 10^{-3}$ & 0.81 & -2.62 & 0.90 & 177.3 & 0.88 \\
& BL & $241.6 \times 10^{-3}$ & 0.93 & -0.11 & 0.30 & -0.4 & 0.26 \\
\hline
\end{tabular}

$11 \mathrm{~km}$, and then flew back at $9.1 \mathrm{~km}$, the altitude of the highest $\mathrm{CO}$ mixing ratios found during the first flight leg. This flight traversed the central part of the simulated Asian plume, for which the model gives a wide vertical distribution from about 5.5 to $11 \mathrm{~km}$, with the highest mixing ratios at the level of the return leg (Fig. 6b). Figure 9 shows the modeled $\mathrm{CO}$ tracer and measured $\mathrm{CO}$ mixing ratios along the flight. According to the model using the ECMWF data input (Fig. 9c), the Asian plume was penetrated on three sections of the flight: from 09:45-10:30 UTC 
(first descent), from 11:00-11:10 UTC (ascent to maximum altitude), and from 11:20-12:00 UTC (level flight back). The model suggests the aircraft to have been in the stratosphere at the two highest sections of the flight (model products not shown here but available from http://zardoz.nilu.no/ andreas/MILAGRO_ETC/), probed North American pollution between about 3 and $5 \mathrm{~km}$, and flown through a mixture of fresh European and aged North American pollution below $3 \mathrm{~km}$. The Asian pollution plume was sandwiched between the stratosphere above and the North American pollution below. The alternative simulations using the GFS data (Fig. 9d) reveal a similar picture but give lower Asian CO tracer mixing ratios. The retroplumes in the Asian plume are very similar to the ones for the previous day (see Fig. 8) and indicate the same source region, and the age distribution of the FFC emissions (Fig. 9b) is consistent with a 1-day aging. Again, the model suggests considerable influence from BB (Fig. 9a).

The CO measurements (Fig. 9) generally confirm the FLEXPART scenario. There are very low CO levels (60$90 \mathrm{ppbv}$ ) in the stratospheric sections of the flight, strongly enhanced $\mathrm{CO}$ values in the Asian plume sections as well as in the boundary layer, and moderate $\mathrm{CO}$ values in the North American plume. The measured $\mathrm{CO}$ values in the North American plume are consistent with the values observed on the previous day (130-140 ppbv), and the highest $\mathrm{CO}$ values in the Asian plume (about $170 \mathrm{ppbv}$ ) are also similar to the previous day.

\subsection{Chemical composition in the Asian pollution plume}

\subsubsection{Flight A - unperturbed Asian pollution}

Figure 10 shows the time series of the flight altitude, the relative humidity $(\mathrm{RH}), \mathrm{CO}, \mathrm{NO}, \mathrm{NO}_{\mathrm{y}}$ and $\mathrm{O}_{3}$ measured during flight A. For the further analysis, we subdivide the time series in several periods. Two periods, labelled NA-I and NA-II and marked with a yellow background contain North American pollution. Four periods, which contain mostly Asian pollution (periods I-III) and possibly a mixture of Asian and North American pollution (period IV) are highlighted with a turquoise background. For periods I-III, the potential temperature (not shown) was almost exactly the same $(320 \pm 1 \mathrm{~K})$, whereas for period IV it was about $3 \mathrm{~K}$ lower. This indicates that the pollution measured during periods IIII originated from the same source region but for period IV the source region may have been different. FLEXPART suggests this to be still mainly Asian pollution but because of the model uncertainties, a North American origin or a mixture of contributions from both regions cannot be excluded for flight segment IV. For comparison purposes, we also label three sequences less influenced by the Asian pollution (BG-I, BGII, BG-III). The periods NA-I, NA-II and I-IV span a large range of values, which makes them particularly suitable for correlation analyses.
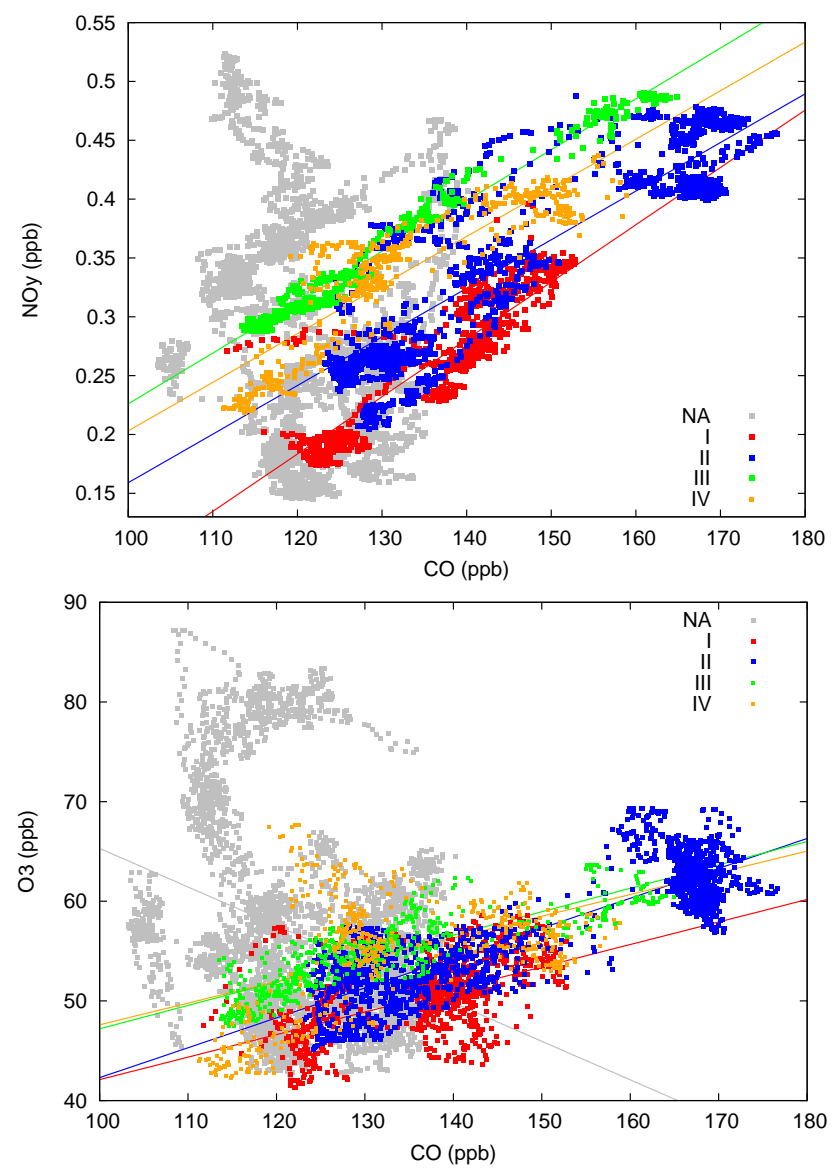

Fig. 11. Scatter plots of $\mathrm{NO}_{\mathrm{y}}$ versus $\mathrm{CO}$ (top) and $\mathrm{O}_{3}$ versus $\mathrm{CO}$ (bottom) for various sections of flight $\mathrm{A}$, with added regression lines through the data where correlations are significant. The data are shown for the Asian plume penetrations I-IV, and combined North American plume encounters NA-I and NA-2, as indicated by the colors and as defined in Fig. 10.

Table 2 lists the mean mixing ratios of $\mathrm{CO}, \mathrm{O}_{3}, \mathrm{NO}$ and $\mathrm{NO}_{\mathrm{y}}$ for the selected periods. For $\mathrm{CO}$ and $\mathrm{O}_{3}$, the excess values over the subjectively determined background values of 115 ppbv and 48 ppbv, respectively are reported, too. The assumed background mixing ratios were derived from the data measured during periods BG-I, BG-II and BG-III outside the major plume sections. $\mathrm{CO}$ background mixing ratios at the low latitudes from where this air mass originated are normally lower than those measured. Thus, these "background" air masses themselves must have been influenced to some extent by Asian emissions and, therefore, the excess values are conservative estimates of the impact of the Asian emissions. CO is strongly enhanced, on average by $17-34 \mathrm{ppbv}$, during the Asian plume penetrations I-IV, with a peak enhancement of more than $60 \mathrm{ppbv}$ during period II. $\mathrm{NO}_{\mathrm{y}}$ mixing ratios are also elevated: Average values range between 0.26 and $0.36 \mathrm{ppbv}$ for periods I-IV, and peak values are 
close to $0.5 \mathrm{ppbv} . \mathrm{O}_{3}$ mixing ratios are not particularly high (50-57 ppbv on average) but clearly enhanced by $2-9 \mathrm{ppbv}$ over the background. Nevertheless, the enhancements stand out from the background variability, and peak $\mathrm{O}_{3}$ mixing ratios during period II reach almost $70 \mathrm{ppbv}, 22 \mathrm{ppbv}$ above the background.

Standard linear regression analyses of 1-s $\mathrm{CO}, \mathrm{NO}_{\mathrm{y}}$ and $\mathrm{O}_{3}$ data were made and the Pearson correlation coefficients were calculated for the different periods marked in Fig. 10. Table 3 gives the corresponding correlation parameters and Fig. 11 shows scatter plots of $\mathrm{NO}_{\mathrm{y}}$ versus $\mathrm{CO}$ and $\mathrm{O}_{3}$ versus $\mathrm{CO}$ data, with superimposed regression lines. There are strongly positive correlations between $\mathrm{CO}$ and $\mathrm{NO}_{\mathrm{y}}$ for periods I-IV (squared correlation coefficients $\mathrm{r}^{2}$ between 0.73 and 0.98 ), with highly consistent slopes of $\Delta \mathrm{NO}_{\mathrm{y}} / \Delta \mathrm{CO}=0.0045 \pm 0.0004$ (Table 3 ). The $\mathrm{NO}_{\mathrm{x}} / \mathrm{CO}$ emission ratio in rural areas of Asia may be as low as 0.03 (Wang et al., 2002), which is much less than the $0.14-0.3$ for FFC emissions in North America reported by Parrish et al. (1991), but the observed $\Delta \mathrm{NO}_{\mathrm{y}} / \Delta \mathrm{CO}$ values are almost an order of magnitude lower than that. This indicates that some $90 \%$ of the $\mathrm{NO}_{\mathrm{y}}$ emitted was removed from the atmosphere before the measurement. This is in agreement with previous findings (Stohl et al., 2002b, for conditions downwind of North America) (Koike et al., 2003; Miyazaki et al., 2003b; Takegawa et al., 2004, for conditions downwind of Asia), that $\mathrm{NO}_{\mathrm{y}}$ is very efficiently scrubbed from the atmosphere upon export from the boundary layer. Although most of the $\mathrm{NO}_{\mathrm{y}}$ was removed and only $5-12 \%$ of the remaining $\mathrm{NO}_{\mathrm{y}}$ was in the form of NO (Table 2), the mean NO levels measured during periods I-III (25-33 pptv) are likely still sufficiently high for this upper tropospheric air mass to be in a net $\mathrm{O}_{3}$ production regime (e.g., Reeves et al., 2002).

There is no correlation $\left(\mathrm{r}^{2}=0.03\right)$ between $\mathrm{CO}$ and $\mathrm{NO}_{\mathrm{y}}$ for periods NA-I and NA-II. Some of the data even show a negative $\mathrm{NO}_{\mathrm{y}} / \mathrm{CO}$ correlation (Fig. 11), which indicates a stratospheric origin. Overall, the $\mathrm{NO}_{\mathrm{y}} / \mathrm{CO}$ correlations for sequences NA-I and NA-II suggest the presence of tropospheric background air weakly perturbed by emissions in North America (FLEXPART produces $\mathrm{CO}$ enhancements of only 15-30 ppbv due to North American FFC emissions) and occasional stratospheric influence.

The $\mathrm{O}_{3} / \mathrm{CO}$ correlations (Fig. 11 and Table 3 ) confirm the above interpretation. Periods NA-I and NA-II show a large scatter of the data, with an overall negative $\mathrm{O}_{3} / \mathrm{CO}$ slope. In contrast, periods I-IV have relatively tight $\mathrm{O}_{3} / \mathrm{CO}$ correlations ( $\mathrm{r}^{2}$ ranging from 0.22 to 0.75 ) and $\Delta \mathrm{O}_{3} / \Delta \mathrm{CO}$ slopes of 0.24-0.30. Again, the similarity of the slopes suggests a common origin of the air masses I-IV. Under the assumptions that both $\mathrm{CO}$ and $\mathrm{O}_{3}$ are conserved during transport and if mixing with surrounding air can be neglected, the $\Delta \mathrm{O}_{3} / \Delta \mathrm{CO}$ slopes give the number of $\mathrm{O}_{3}$ molecules formed per CO molecule emitted. For aged North American FFC plumes in the North Atlantic region, Parrish et al. (1998) reported average $\Delta \mathrm{O}_{3} / \Delta \mathrm{CO}$ values of $0.25-0.40$, and for the
Azores, Honrath et al. (2004) reported a rather high value of 1.0 (both for summer conditions). For aged BB plumes, the $\Delta \mathrm{O}_{3} / \Delta \mathrm{CO}$ values are normally lower (e.g., $0.05-0.11$ according to Wotawa and Trainer, 2000). The $\Delta \mathrm{O}_{3} / \Delta \mathrm{CO}$ slopes of 0.24-0.30 in the Asian plume are at the lower end of the values reported for FFC emissions but they are consistent with $\Delta \mathrm{O}_{3} / \Delta \mathrm{CO}$ slopes of $0.2-0.5$ observed in Asian pollution plumes over North America (Price et al., 2004). In summary, the $\mathrm{O}_{3}$ formation efficiency based on $\mathrm{CO}$ was not particularly high in our case, which could be due to the lower $\mathrm{NO}_{\mathrm{x}} / \mathrm{CO}$ emission ratio in Asia than elsewhere (Wang et al., 2002), or an admixture of BB emissions. $\mathrm{O}_{3}$ is also tightly correlated $\left(\mathrm{r}^{2}\right.$ ranging from 0.38 to 0.79$)$ with $\mathrm{NO}_{\mathrm{y}}$ for periods I-IV (Table 3), and the $\Delta \mathrm{O}_{3} / \Delta \mathrm{NO}_{\mathrm{y}}$ slopes range from 45 to 77 , which is comparable to the slope of 60 reported by Miyazaki et al. (2003a) in the Asian outflow in spring.

\subsubsection{Flight B - Asian pollution mixing with stratospheric air}

Figure 12 shows the time series of the trace gas measurements for flight B. Five flight segments (I-V, highlighted in turquoise in Fig. 12) have been identified as penetrations of the Asian plume, during two periods the aircraft flew in the stratosphere (S-I, S-II, highlighted in yellow), and one period marks the descent into the boundary layer at the point of return (BL, pink). The $\mathrm{CO}$ data bear clear signatures of the Asian plume penetrations, with average $\mathrm{CO}$ concentrations being actually somewhat higher than on the previous day, although the enhancements stand out somewhat less clearly because of a higher background (Table 2). Figure 13 shows $\mathrm{NO}_{\mathrm{y}} / \mathrm{CO}$ and $\mathrm{O}_{3} / \mathrm{CO}$ scatter plots, and Table 3 summarizes the correlation parameters. Periods S-I and S-II have negative $\Delta \mathrm{NO}_{\mathrm{y}} / \Delta \mathrm{CO}$ and $\Delta \mathrm{O}_{3} / \Delta \mathrm{CO}$ slopes, which are characteristic for stratospheric air. Segment BL has a very large $\Delta \mathrm{NO}_{\mathrm{y}} / \Delta \mathrm{CO}$ slope and a slightly negative $\Delta \mathrm{O}_{3} / \Delta \mathrm{CO}$ slope, which is characteristic of fresh emissions where $\mathrm{NO}_{\mathrm{y}}$ removal and $\mathrm{O}_{3}$ formation have not occurred yet (note that $\mathrm{NO}_{\mathrm{y}}$ mixing ratios of up to $10 \mathrm{ppbv}$ were measured in the BL, which are not shown in Fig. 12 and 13).

The $\mathrm{NO}_{\mathrm{y}} / \mathrm{CO}$ scatter plot also reveals frequent encounters of aircraft exhaust plumes, which are characterized by large enhancements in $\mathrm{NO}_{\mathrm{y}}$ and $\mathrm{NO}$ but small $\mathrm{CO}$ signals. This is most noticeable during period S-II but also during periods I and V. Notes made by the mission scientist (B. Weinzierl) during the flight document the frequent encounter of aircraft contrails at the higher flight levels.

Of the Asian plume penetrations I-V, only period III has a chemical composition that is comparable to the Asian plume observed during flight A. During period III, the observed mixing ratios of $\mathrm{CO}, \mathrm{O}_{3}, \mathrm{NO}$ and $\mathrm{NO}_{\mathrm{y}}$ are all very similar to the values observed on the previous day (Table 2) and also the trace gas correlations are almost the same (Table 3$)$. The potential temperatures $(310-315 \mathrm{~K})$ are about 5$10 \mathrm{~K}$ lower than those measured in the Asian plume on the 


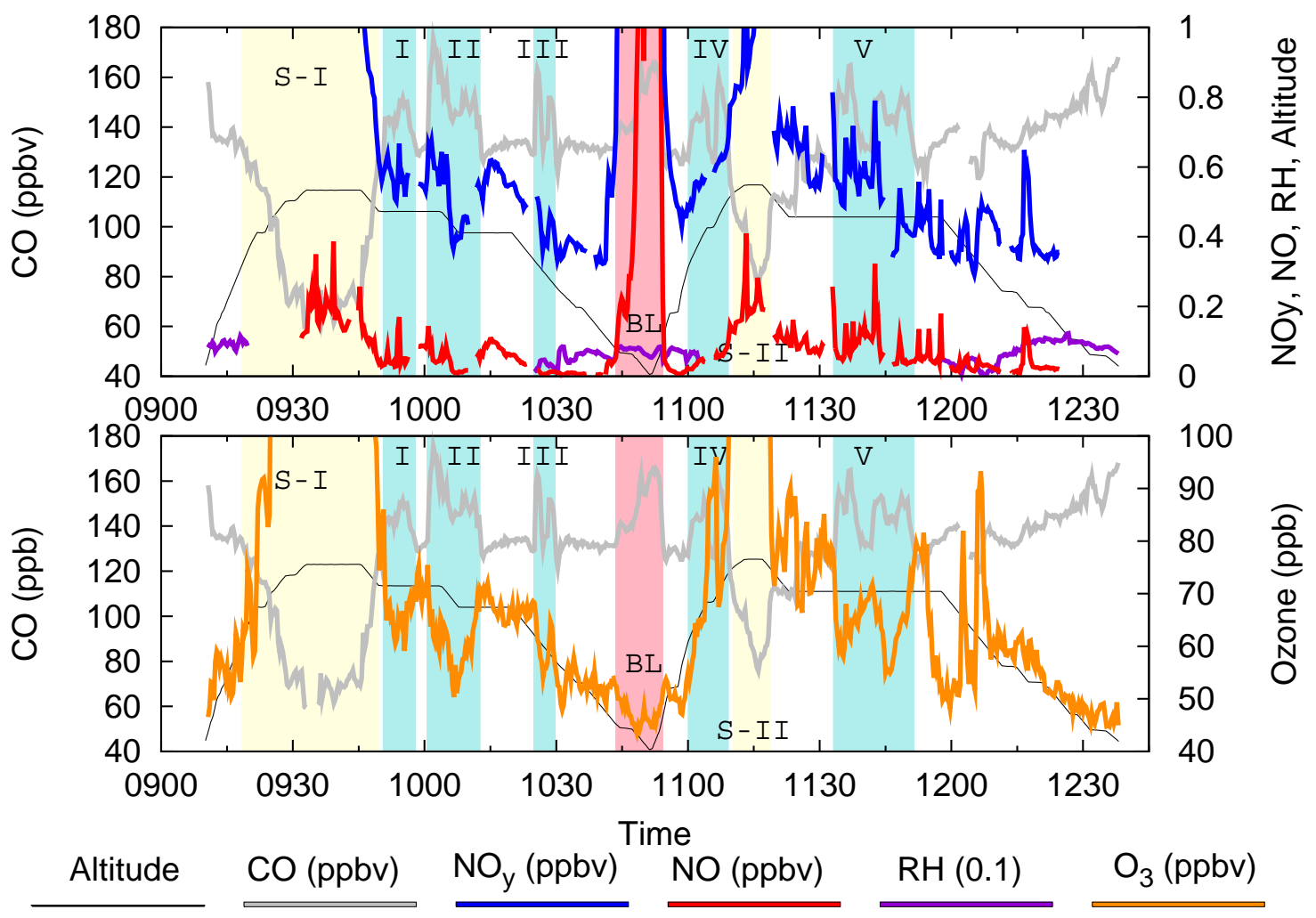

Fig. 12. Same as Fig. 10, but for flight B on 25 March 2006. Possible Asian plume penetrations are numbered I-V and highlighted by a turquoise background, stratospheric flight sections are labelled S-I and S-II and highlighted in yellow, and the descent into the boundary layer is labelled BL and highlighted in pink, respectively.

day before, indicating that not exactly the same air mass was flown through. However, a radiational cooling of about 1$2 \mathrm{~K} /$ day in clear-sky conditions and more in the presence of cirrus clouds can partly explain the decrease. The remaining periods I, II, IV and $\mathrm{V}$ are characterized by higher $\mathrm{O}_{3}$ and $\mathrm{NO}_{y}$ mixing ratios, as well as small or negative $\Delta \mathrm{O}_{3} / \Delta \mathrm{CO}$ and $\Delta \mathrm{NO}_{\mathrm{y}} / \Delta \mathrm{CO}$ slopes and low correlation coefficients, despite the fact that the high $\mathrm{CO}$ mixing ratios indicate polluted conditions. The reason for this is that the Asian pollution plume was mixing with stratospheric air at almost the same potential temperatures (mostly $315 \mathrm{~K}$ but up to $321 \mathrm{~K}$ in segment IV) as measured in segment III. Most of the data points for periods I, II, IV and $\mathrm{V}$ in the $\mathrm{O}_{3} / \mathrm{CO}$ (and less clearly, also in the $\mathrm{NO}_{\mathrm{y}} / \mathrm{CO}$ ) scatter plot are lying above the regression line for period III and to the right of the regression lines for periods S-I and S-II. This is a clear signature of the mixing between polluted and stratospheric air, reminiscent of similar cases presented by Parrish et al. (2000) and Cooper et al. (2004a).

Figure 14 presents a plot of $\mathrm{O}_{3}$ and $\mathrm{CO}$ versus altitude for a short period of the flight from the end of segment IV to the beginning of segment S-II, which clearly shows the mixing between polluted and stratospheric air. This profile was obtained just to the west of the position marked with a cross in the water vapor satellite image (Fig. 5, bottom), in a generally very dry upper tropospheric air mass. Between 6 and $8 \mathrm{~km}$, both $\mathrm{O}_{3}$ and $\mathrm{CO}$ increase with altitude as the aircraft ascended into the Asian pollution plume. At about $8.7 \mathrm{~km}$, a thin layer of stratospheric origin is embedded in the Asian plume, with low $\mathrm{CO}$ and high $\mathrm{O}_{3}$ mixing ratios. $\mathrm{CO}$ increased and $\mathrm{O}_{3}$ decreased again above this layer before the aircraft finally ascended into the stratosphere above $10 \mathrm{~km}$. Interestingly, $\mathrm{O}_{3}$ and $\mathrm{CO}$ are strongly anticorrelated between the layer of stratospheric origin and the stratosphere, even though the highest $\mathrm{CO}$ values occur there at $9 \mathrm{~km}$. This can only be interpreted as the result of mixing between stratospheric air masses and the Asian pollution plume.

While the chemical data clearly shows the effect of the mixing, it would be interesting to know whether this mixing has occurred earlier, or was still in progress as the aircraft performed the sounding. The mission scientist (B. Weinzierl) reported that the ascent was bumpy, suggesting active turbulence. Also shown in Fig. 14 are the potential temperature $\Theta$ and wind velocity $(\mathrm{FF})$. There are several altitudes where the $\Theta$ profile indicates that the thermal stratification of the atmosphere was only weakly stable, neutral, or in some cases maybe even slightly unstable, e.g., between about $8 \mathrm{~km}$ and the layer of stratospheric origin. The unstable layers are 

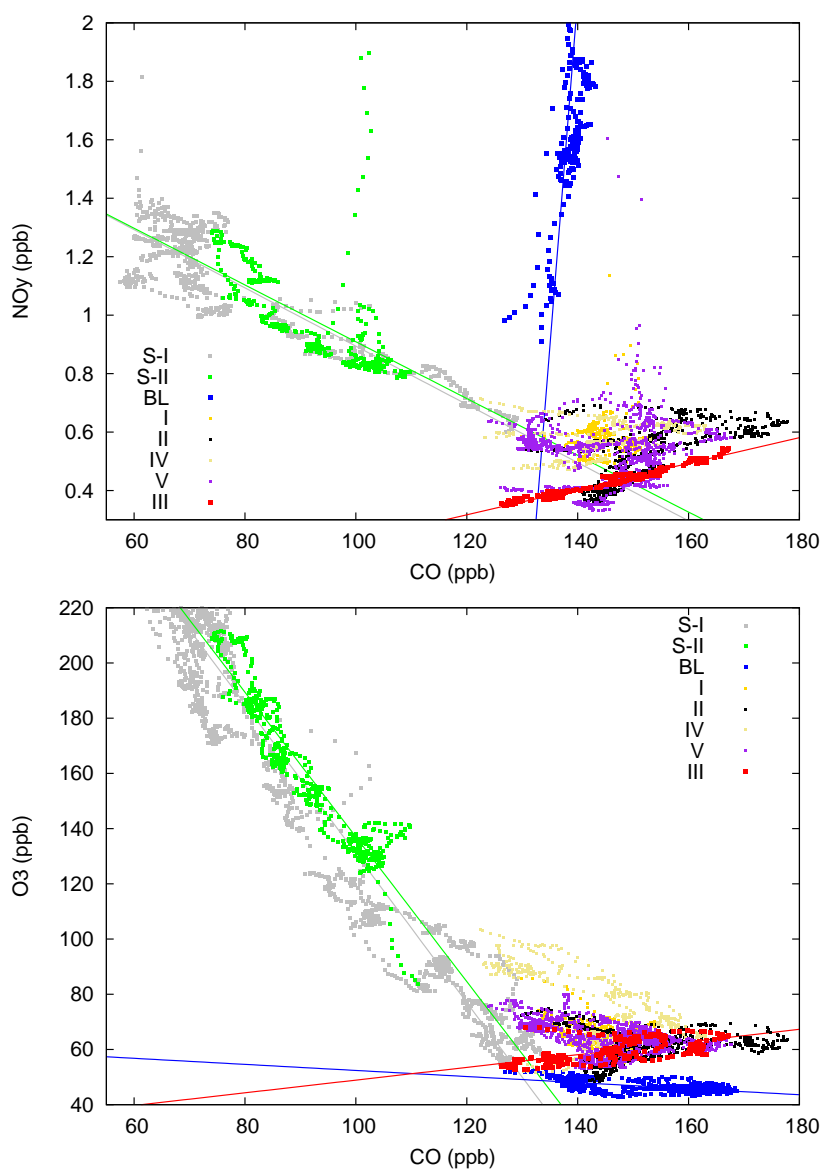

Fig. 13. Scatter plots of $\mathrm{NO}_{\mathrm{y}}$ versus $\mathrm{CO}$ (top) and $\mathrm{O}_{3}$ versus $\mathrm{CO}$ (bottom) for various segments of flight $\mathrm{B}$. The data are shown for the Asian plume penetrations I-V, stratospheric sections S-I and SII, and the boundary layer flight segment $\mathrm{BL}$, as indicated by the colors and as defined in Fig. 12. Regression lines are shown for segments S-I, S-II, BL and III, which feature tight correlations.

possibly an artefact of the slantwise ascent of the aircraft and a short horizontal flight segment. However, the deeper neutral or only slightly stable layers must be real. In addition, there is substantial wind shear in some of these layers.

In order to identify turbulent layers, we calculated the Richardson number (Stull, 1988)

$R i=\frac{\frac{g}{\Theta} \frac{\Delta \Theta}{\Delta z}}{\left(\frac{\Delta u}{\Delta z}\right)^{2}+\left(\frac{\Delta v}{\Delta z}\right)^{2}}$

where $g$ is the acceleration due to gravity, $u$ and $v$ are the zonal and meridional wind components, $\bar{\Theta}$ is the average potential temperature of two subsequent measurements, and $z$ is the altitude. To reduce the effect of instrumental noise, $R i$ was calculated on the basis of 10 -s averages. Values of $R i$ smaller than about 0.21 to 0.25 indicate an almost $100 \%$ probability of the occurrence of turbulence, since even an

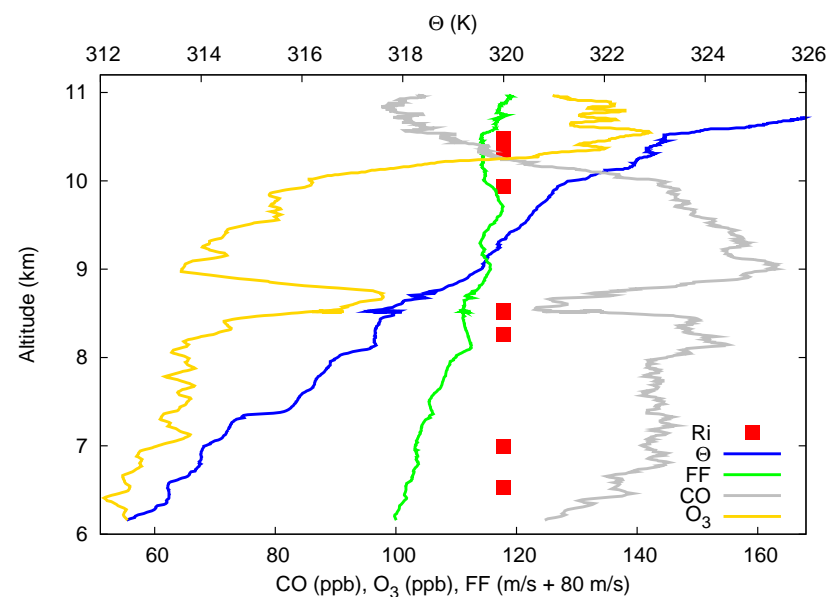

Fig. 14. Vertical profile of $\mathrm{CO}, \mathrm{O}_{3}, \Theta$, and wind velocity (FF) measured during flight $\mathrm{B}$ between 11:00 and 11:13 UTC. Furthermore, altitudes with $R i<0.2$ are marked with red dots.

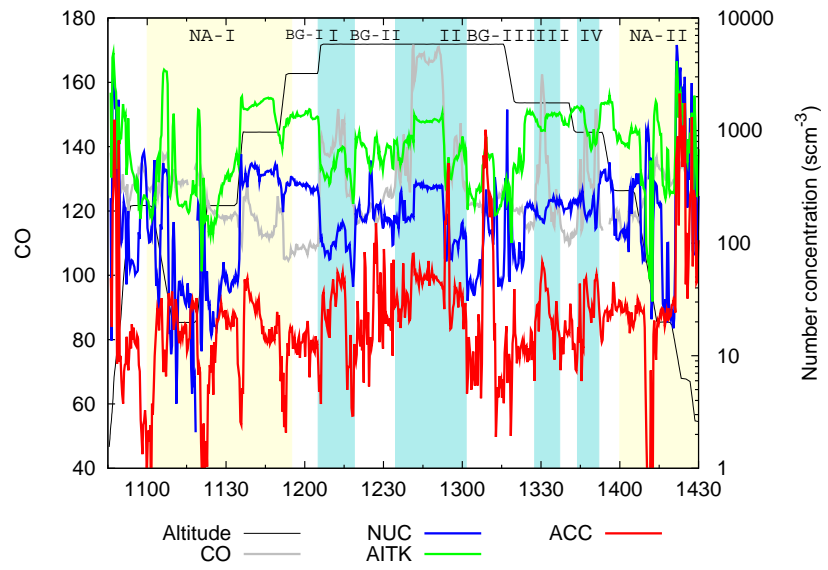

Fig. 15. Time series of the number concentrations of nucleation (NUC), Aitken (AITK) and accumulation (ACC) mode particles measured during flight $\mathrm{A}$ on 24 March 2006. Flight altitudes are shown in relative units. The time series were smoothed by calculating 20-s running means from the original 1-s data. Periods with encounters of North American pollution are marked with yellow background and are labelled NA-I and NA-II. Four penetrations of the Asian plume are highlighted with turquoise background and are labelled I-IV. Three "background" periods are labelled BG-I, BG-II and BG-III.

originally laminar flow would become turbulent at these values (Stull, 1988). The altitudes with $R i<0.2$ are marked with red dots in Fig. 14. According to this analysis, turbulent layers occurred within the Asian plume below $7 \mathrm{~km}$, just below the layer of stratospheric origin at 8 to $8.5 \mathrm{~km}$, and below the tropopause at around $10 \mathrm{~km}$. Note that $R i<0.2$ is a very conservative threshold for the occurrence of turbulence, especially when working with the 10-s data. Thus, turbulence probably also occurred at other altitudes or in deeper layers. 
This shows that the turbulent mixing was still active when the measurements were taken. Asian pollution was also mixed into the stratosphere, since the $\mathrm{CO}$ mixing ratios at the highest flight altitudes, already in the stratosphere, were clearly above the normal stratospheric mixing ratios. In fact, much lower CO mixing ratios were found at $11 \mathrm{~km}$ a few minutes after the vertical profile shown in Fig. 14 was completed (see Fig. 12). The meteorological situation was favorable for this mixing to occur, since stratospheric air masses descended on the rear of the trough located over Europe on 25 March (Fig. 2h).

Pollution from Eastern Asia is very often lifted by warm conveyor belts to altitudes near the tropopause (Stohl, 2001; Eckhardt et al., 2004), which was also the case here. Eckhardt et al. (2004) found in their model study that approximately $6 \%$ of the mass of the warm conveyor belts ascending over the North Pacific can be found in the stratosphere after 5 days. Thus, we suggest that the mixing of stratospheric air into the Asian pollution in the troposphere, as well as the mixing of Asian pollution into the stratosphere, both of which were observed during flight $\mathrm{B}$, are characteristic features of Asian pollution plumes.

\subsection{Aerosol characterization}

Regarding the aerosol characterization, we focus our analysis on flight A because the frequent encounter of aircraft contrails and the large variability of the measured data obtained during flight $\mathrm{B}$ made it difficult to determine some of the aerosol parameters. Figure 15 presents the time series of the number concentrations of nucleation mode, Aitken, and accumulation mode particles measured during flight $\mathrm{A}$, and Table 4 lists the mean values and 90-percentiles of various aerosol parameters for different segments of flight A. The segments of the Asian plume penetrations I-IV are the same as used previously (Fig. 10) but the periods NA-I, NAII and BG-I, BG-II, BG-III could not be used to determine average aerosol parameters because the PSAP measurements require a constant flight altitude. Furthermore, some of these sequences contained cloudy periods, which had very different aerosol characteristics than the cloud-free periods. Therefore, for comparison with the Asian plume values in Table 4 we present averages over two periods with less influence from Asian pollution, one non-cloudy sequence (FT, from 11:52:25 to $11: 58: 59$ UTC, corresponding approximately to BG-I in Fig. 15), and one sequence in cirrus clouds (FT cirrus, from 13:01:30 to 13:07:15 UTC, corresponding to the first part of BG-III in Fig. 15).

The nucleation mode and Aitken particle number concentrations are lowest in the relatively clean cirrus cloud sequence and highest in the also relatively clean FT sequence (Table 4). The high concentrations in the cloud-free FT sequence are likely the result of new particle formation, which is known to be particularly effective in the outflow of clouds (Perry and Hobbs, 1994), and the FT air mass was lifted in

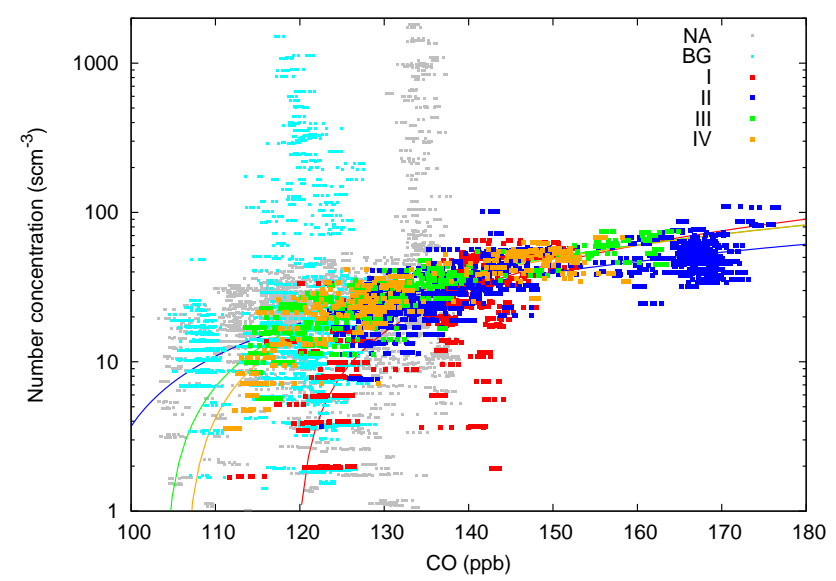

Fig. 16. Scatter plot of the number concentrations of accumulation mode aerosols versus $\mathrm{CO}$ for various sections of flight $\mathrm{A}$, with added regression lines through the data where correlations are significant. The data are shown for the Asian plume penetrations I-IV, and combined North American plume encounters NA-I and NA-2, as well as combined "background" conditions BG-I, BG-II and BGIII as defined in Fig. 10. For period II, a 1.5-min segment containing an unexplained spike in the accumulation mode aerosol number concentrations (see Fig. 15) was removed from the correlation analysis.

the WCB. Compared to the FT segment, the Aitken and, particularly, the nucleation mode particles are suppressed during the Asian plume penetrations I-IV. A correlation analysis with CO (Table 5) reveals no systematic dependence of nucleation mode and Aitken particles on the CO levels: There is little correlation for periods I and IV, a strong positive correlation for period II, and a strong negative correlation for period III, as can also be seen in Fig. 15. Thus, it seems that new particle formation was generally suppressed in the Asian pollution plume, likely due to the high concentrations of transported larger particles (see below). However, the actual variability in nucleation mode particles within the plume cannot be explained by simple correlations with $\mathrm{CO}$ and, thus, does not primarily depend on the pollution load. Other factors, such as the degree of previous cloud processing, the relative humidity, and occasional encounters of cirrus clouds during period II, seem to have been more important.

Accumulation mode particles are strongly enhanced during the Asian pollution plume penetrations I-IV, with mean number concentrations about a factor of three higher than during periods FT and "FT cirrus" (Table 4). The mean concentrations are also higher than during the rest of the flight, except for a maximum during period BG-III, which is probably related to a cirrus cloud encounter where breaking ice crystals disturb the PCASP measurements, and except for the high concentrations in the boundary layer just after the take-off and before landing (Fig. 15). There are strong positive correlations of accumulation mode particle number 
Table 4. Mean and 90-percentile (P90) particle number concentrations for the Asian plume encounters I-IV of flight A (see Fig. 10). For comparison, a non-cloudy period with less influence from Asian pollution (FT, from 11:52:25 to 11:58:59 UTC, corresponding approximately to BG-I in Fig. 10) and a relatively clean sequence in cirrus clouds (FT cirrus, from 13:01:30 to 13:07:15 UTC, corresponding to the first part of BG-III in Fig. 10) are also shown. Values in parenthesis give the standard deviation of the average over the analysed time sequence, i.e., they reflect atmospheric variability. Number concentration values are given for standard conditions $(273 \mathrm{~K}, 1013 \mathrm{hPa})$ which correspond to altitude invariant mixing ratios.

\begin{tabular}{|c|c|c|c|c|c|c|c|c|c|c|}
\hline Period & $\begin{array}{l}\text { mean } \\
\text { NUC } \\
\mathrm{scm}^{-3}\end{array}$ & $\begin{array}{l}\mathrm{P} 90 \\
\text { NUC } \\
\mathrm{scm}^{-3}\end{array}$ & $\begin{array}{l}\text { mean } \\
\text { AITK } \\
\mathrm{scm}^{-3}\end{array}$ & $\begin{array}{l}\text { P90 } \\
\text { AITK } \\
\mathrm{scm}^{-3}\end{array}$ & $\begin{array}{l}\text { mean } \\
\text { ACC } \\
\mathrm{scm}^{-3}\end{array}$ & $\begin{array}{l}\mathrm{P} 90 \\
\mathrm{ACC} \\
\mathrm{scm}^{-3}\end{array}$ & $\begin{array}{l}\text { mean } \\
\text { AITK } \\
\text { nonvol } \\
\mathrm{scm}^{-3}\end{array}$ & $\begin{array}{l}\text { P90 } \\
\text { AITK } \\
\text { nonvol } \\
\mathrm{scm}^{-3}\end{array}$ & $\begin{array}{l}F_{\text {nonvol }} \\
(\text { AITK) }\end{array}$ & $\begin{array}{l}\sigma_{a p} \\
\mathrm{Mm}^{-1}\end{array}$ \\
\hline I & $\begin{array}{l}110 \\
(68)\end{array}$ & 168 & $\begin{array}{l}524 \\
(235)\end{array}$ & 728 & $\begin{array}{l}26 \\
(18)\end{array}$ & 52 & $\begin{array}{l}102 \\
(44)\end{array}$ & 165 & $\begin{array}{l}20 \\
(5)\end{array}$ & 0.25 \\
\hline II & $\begin{array}{l}215 \\
(105)\end{array}$ & 341 & $\begin{array}{l}888 \\
(324)\end{array}$ & 1260 & $\begin{array}{l}40 \\
(12)\end{array}$ & 68 & $\begin{array}{l}207 \\
(71)\end{array}$ & 286 & $\begin{array}{l}24 \\
(3)\end{array}$ & n.a. ${ }^{\#}$ \\
\hline III & $\begin{array}{l}204 \\
(55)\end{array}$ & 262 & $\begin{array}{l}1261 \\
(167)\end{array}$ & 1427 & $\begin{array}{l}30 \\
(17)\end{array}$ & 46 & $\begin{array}{l}255 \\
(42)\end{array}$ & 327 & $\begin{array}{l}21 \\
(5)\end{array}$ & 0.40 \\
\hline IV & $\begin{array}{l}214 \\
(70)\end{array}$ & 285 & $\begin{array}{l}1101 \\
(337)\end{array}$ & 1613 & $\begin{array}{l}31 \\
(16)\end{array}$ & 53 & $\begin{array}{l}216 \\
(61)\end{array}$ & 296 & $\begin{array}{l}21 \\
(7)\end{array}$ & 0.70 \\
\hline I-IV mean & 186 & & 944 & & 32 & & 195 & & 22 & \\
\hline FT & $\begin{array}{l}342 \\
(38)\end{array}$ & 396 & $\begin{array}{l}1312 \\
(93)\end{array}$ & 1420 & $\begin{array}{l}12 \\
(5)\end{array}$ & 20 & $\begin{array}{l}150 \\
(14)\end{array}$ & 166 & $\begin{array}{l}11 \\
(1)\end{array}$ & $<0.10$ \\
\hline FT cirrus & $\begin{array}{l}46 \\
(18)\end{array}$ & 67 & $\begin{array}{l}270 \\
(56)\end{array}$ & 328 & $\begin{array}{l}10 \\
(10)\end{array}$ & 18 & $\begin{array}{l}40 \\
(12)\end{array}$ & 49 & $\begin{array}{l}15 \\
(3)\end{array}$ & $<0.10$ \\
\hline
\end{tabular}

\# For sequence II, the PSAP signal was corrupted by cirrus cloud encounters.

Table 5. Correlations between the number concentrations of nucleation mode, Aitken, and accumulation mode aerosols, respectively, and $\mathrm{CO}$ during the periods NA-I, NA-II, and Asian plume encounters I-IV of flight A as defined in Fig. 10. Squared correlation coefficients ( $\mathrm{r}^{2}$ ) and slopes of the regression lines are reported. For period II, a 1.5-min segment containing an unexplained spike in the accumulation mode aerosol number concentrations (see Fig. 15 was removed from the correlation analysis.

\begin{tabular}{ccccccc}
\hline Period & $\begin{array}{c}\Delta \mathrm{NUC} / \Delta \mathrm{CO} \\
\mathrm{scm}^{-3} \mathrm{ppbv}^{-3}\end{array}$ & $\mathrm{r}^{2}$ & $\begin{array}{c}\Delta \mathrm{AITK} / \Delta \mathrm{CO} \\
\mathrm{scm}^{-3} \mathrm{ppbv}^{-3}\end{array}$ & $\mathrm{r}^{2}$ & $\begin{array}{c}\Delta \mathrm{ACC} / \Delta \mathrm{CO} \\
\mathrm{scm}^{-3} \mathrm{ppbv}^{-3}\end{array}$ & $\mathrm{r}^{2}$ \\
\hline NA-I & -8.1 & 0.11 & -14.6 & 0.02 & 0.1 & 0.00 \\
NA-II & 47.5 & 0.09 & 16.5 & 0.02 & 16.5 & 0.07 \\
I & 1.3 & 0.08 & 6.76 & 0.13 & 1.5 & 0.57 \\
II & 4.6 & 0.57 & 16.3 & 0.74 & 0.8 & 0.51 \\
III & -2.0 & 0.45 & -9.8 & 0.68 & 1.1 & 0.84 \\
IV & -2.4 & 0.18 & -12.2 & 0.21 & 1.1 & 0.80 \\
\hline
\end{tabular}

concentrations with $\mathrm{CO}$ during all Asian plume encounters (Table 5) with consistent slopes of $1.1 \pm 0.35 \mathrm{scm}^{-3} \mathrm{ppbv}^{-3}$ CO. A scatter plot (Fig. 16) shows that these tight correlations occur only during the Asian plume encounters, whereas the data for the remainder of the flight are poorly correlated (see also Table 5 and Fig. 15). The correlation coefficient for period II is the lowest of all found for the Asian plume encounters. This is probably related to cirrus cloud encounters during that period. In summary, this provides clear evidence for the long-range transport of accumulation mode aerosols from Asia to Europe.
Figure 17 shows the aerosol number and volume size distributions from the accumulation mode to the coarse particle mode, for the Asian plume penetrations I-IV and for the FT segment. The greater concentrations of accumulation mode aerosols in the Asian plume extend to a size of about $0.5 \mu \mathrm{m}$. For larger particle sizes, the periods I and FT show larger particle concentrations than periods II, III and IV. In fact, the period I and FT size distributions indicate the presence of a relatively large number of super-micron particles, whose contribution to the total particle volume (and particle mass) is comparable to those of the accumulation mode aerosols. The 

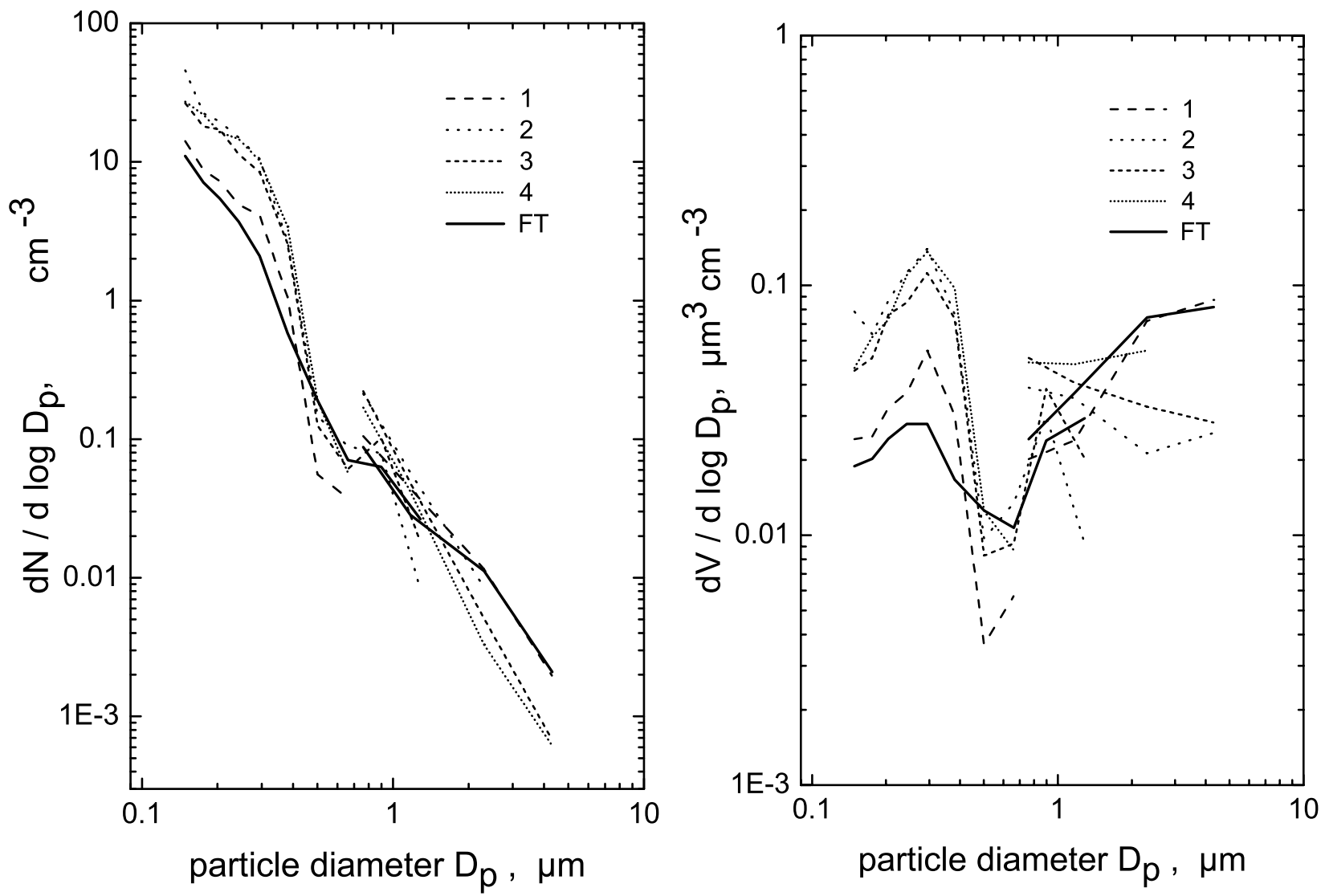

Fig. 17. Average aerosol size distributions for the Asian plume penetrations during sequences I, II, III and IV of flight A, and for a relatively clean sequence (FT) as specified in Table 4. Number densities are shown in the top panel, and volume densities in the bottom panel.

FLEXPART retroplumes suggest that the air masses sampled during periods FT and I originated from slightly further north in Asia than the air masses sampled later. In particular, they travelled over potential dust emission areas such as the Gobi and Takla-Makan deserts and, thus, are more likely to have picked up desert dust than the air masses flown through in segments II, III and IV (see modeling products available at http://zardoz.nilu.no/ andreas/MILAGRO_ETC/). In summary, we conclude that the air masses encountered during period FT contained mostly desert dust, periods II, III, and IV contained mostly anthropogenic pollution aerosols in the accumulation mode, and period I contained a mixture of both. In fact, in Asia it is quite typical that anthropogenic pollution mixes with desert dust (Arimoto et al., 2006). It is also known that the dust can be transported over intercontinental distances (Husar et al., 2001), and Asian dust-pollution mixtures have also been observed over North America (Price et al., 2004).

The fraction of non-volatile Aitken particles in the Asian plume (20-24\%) is about twice as high as for the background period FT and $50 \%$ higher than during "FT cirrus" (Table 4). Furthermore, the light absorption coefficient in the
Asian plume (Table 4) is enhanced $\left(0.25-0.70 \mathrm{Mm}^{-1}\right.$, corresponding to $\left.0.04-0.09 \mu \mathrm{g} \mathrm{m}^{-3} \mathrm{EBC}\right)$ compared to the background conditions $\left(<0.1 \mathrm{Mm}^{-1}\right)$. Since $\mathrm{BC}$ is an important component of the non-volatile fraction of the aerosols and is also responsible for the bulk of the light absorption, we conclude that $\mathrm{BC}$ was enhanced in the Asian plume. The observed fraction of non-volatile Aitken particles is typical for FFC emissions. Engler et al. (2006) report, e.g., a number fraction of $17 \%$ for non-volatile particles in an urban environment. On the other hand, previous observations in BB plumes transported from North America to Europe indicate that most of the Aitken particles were internally mixed and had a non-volatile core, i.e., a much larger fraction of non-volatile Aitken particles (Petzold et al., 2007²). Thus, the contribution of $\mathrm{BB}$ to the aerosols observed in the Asian plume was probably small.

\footnotetext{
${ }^{2}$ Petzold, A., Weinzierl, B., Huntrieser, H., Stohl, A., Real, E., et al.: Perturbation of the European free troposphere aerosol by North American forest fire plumes during the ICARTT-ITOP experiment in summer 2004, Atmos. Chem. Phys. Discuss., in preparation, 2007.
} 


\section{Conclusions}

For the first time, we have intentionally flown a research aircraft over Europe into a pollution plume originating from Asia, which had travelled over an almost hemispheric-scale distance across the North Pacific, North America, and the North Atlantic to Europe. The aircraft carried a large suite of instruments for trace gas and aerosol measurements, which allowed a detailed characterization of the chemical composition and aerosol content of the Asian pollution plume. The plume was sampled on two subsequent days, on the first day west of Spain in an otherwise largely unperturbed environment; on the second day, over Southern Europe, when the plume was already mixing with stratospheric air masses and was also contaminated by aircraft emissions over the continent. Our conclusions from this study are the following:

- There was excellent agreement between the transport of the Asian pollution plume as simulated by FLEXPART and CO retrieved from AIRS for the entire transport event. The FLEXPART forecasts were accurate enough to successfully guide the aircraft into this pollution plume, which had travelled over an almost hemispheric distance. Though the internal plume variability was not well resolved by the model and the plume was predicted at somewhat too high altitudes, the geographical location of the plume was well predicted. The Asian plume was found on both days and, during each flight, was penetrated several times.

- On the first day, CO was increased by $17-34$ ppbv on average (maximum $60 \mathrm{ppbv}$ ) during different plume penetrations, and $\mathrm{O}_{3}$ was increased by $2-9$ ppbv on average (maximum $22 \mathrm{ppbv}$ ), over a background that was itself likely elevated by Asian emissions. $\mathrm{NO}_{\mathrm{y}}$ concentrations were also clearly increased $(0.26-0.36 \mathrm{ppbv})$.

- Trace gas correlations between $\mathrm{CO}, \mathrm{NO}_{\mathrm{y}}$ and $\mathrm{O}_{3}$ were all positive for flight $\mathrm{A}$, indicating net ozone formation in the Asian plume. The observed $\Delta \mathrm{O}_{3} / \Delta \mathrm{CO}$ slopes of $0.22-0.30$ indicate a moderate ozone production efficiency, in agreement with previous observations in Asian pollution plumes. The very low $\Delta \mathrm{NO}_{\mathrm{y}} / \Delta \mathrm{CO}$ slopes of 0.0041-0.0049 indicate that most of the $\mathrm{NO}_{\mathrm{y}}$ emitted in Asia had already been removed from the air mass before the aircraft sampled it.

- Nucleation mode and Aitken particles were reduced in the Asian pollution plume, probably due to large concentrations of pre-existing transported accumulation mode aerosols. The accumulation mode aerosols were clearly enhanced in the pollution plume and well correlated with $\mathrm{CO}$. The aerosol light absorption coefficient and the fraction of non-volatile Aitken particles were also enhanced, pointing towards increased BC levels in the Asian plume. Furthermore, in parts of the Asian plume but also in some neighboring cleaner air masses large concentrations of coarse particles were found, suggesting transport of desert dust from Asia.

- On the second day, the Asian pollution plume was observed to be mixing with stratospheric air. While stratospheric air was mixing into the tropospheric pollution plume, the Asian pollution was also mixing into the stratosphere. The mixing was due to turbulence which was still active at the time of the flight, as is suggested by the measured vertical profiles of potential temperature and derived Richardson numbers, as well as turbulence encounters reported by the mission scientist on board the aircraft. The correlations between the trace gases $\mathrm{O}_{3}, \mathrm{CO}$ and $\mathrm{NO}_{\mathrm{y}}$ clearly show the effect of this mixing. This may be a characteristic feature of Asian pollution plumes because over the North Pacific Ocean they are typically transported into the upper troposphere where the chances of mixing with stratospheric air are largest.

Acknowledgements. We would like to thank M. Lichtenstern, P. Stock, H. Rüba (DLR-IPA) and the crew of the DLR-FB for their help in acquiring this data set. We thank the University of Maryland for providing their global land cover dataset, as well as the MODIS fire detections from their ftp server ftp://mapsftp.geog.umd.edu/. The flight hours were sponsored by the European Commission in the framework of EUFAR, and the research was supported by the Norwegian Research Council (project 169839/D 15). We thank the reviewers for their comments.

Edited by: R. Cohen

\section{References}

Andreae, M. O., Berresheim, H., Andreae, T. W., et al.: Vertical distribution of dimethylsulfide, sulfur dioxide, aerosol ions, and radon over the North-East Pacific Ocean, J. Atmos. Chem., 6, 149-173, 1988.

Arimoto, R., Kim, Y. J., Kim, Y. P., Quinn, P. K., Bates, T. S., et al.: Characterization of Asian dust during ACE-Asia, Glob. Planet. Change, 52, 23-56, 2006.

Arnott, W. P., Moosmüller, H., Sheridan, P. J., Ogren, J. A., Raspet, R., Slaton, W. V., Hand, J. L., Kreidenweis, S. M., and Collett Jr., J. L.: Photoacoustic and filter-based ambient aerosol light absorption measurements: Instrument comparisons and the role of relative humidity, J. Geophys. Res., 108, 4034, doi:10.1029/2002JD002165, 2003.

Auvray, M. and Bey I.: Long-range transport to Europe: Seasonal variations and implications for the European ozone budget, J. Geophys. Res., 110, D11303, doi:10.1029/2004JD005503, 2005.

Berntsen, T. K., Karlsdottir, S., and Jaffe, D. A: Influence of Asian emissions on the composition of air reaching the North Western United States, Geophys. Res. Lett., 26, 22 171-22 174, 1999.

Bond, T. C., Anderson, T. L., and Campbell, D.: Calibration and intercomparison of filter-based measurements of visible light absorption by aerosols, Aerosol Sci. Technol., 30, 582-600, 1999. 
Bond, T. C. and Bergstrom, R. W.: Light absorption by carbonaceous particles: An investigative review, Aerosol Sci. Technol., 40, 27-67, 2006.

Cooper, O. F., C., Parrish, D., Dunlea, E., Hübler, G., Fehsenfeld, F., Holloway, J.,Oltmans, S., Johnson, B., Wimmers, A., and Horowitz, L.: On the life cycle of a stratospheric intrusion and its dispersion into polluted warm conveyor belts, J. Geophys. Res., 109, D23S09, doi:10.1029/2003JD004006, 2004.

Cooper, O. R., Forster, C., Parrish, D., Trainer, M., Dunlea, E., Ryerson, T., Hübler, G., Fehsenfeld, F., Nicks, D., Holloway, J., de Gouw, J., Warneke, C., Roberts, J. M., Flocke, F., and Moody, J.: A case study of transpacific warm conveyor belt transport: Influence of merging airstreams on trace gas import to North America, J. Geophys. Res., 109, D23S08, doi:10.1029/2003JD003624, 2004.

Damoah, R., Spichtinger, N., Forster, C., James, P., Mattis, I., Wandinger, U., Beirle, S., and Stohl, A.: Around the world in 17 days - hemispheric-scale transport of forest fire smoke from Russia in May 2003, Atmos. Chem. Phys., 4, 1311-1321, 2004, http://www.atmos-chem-phys.net/4/1311/2004/.

Eckhardt, S., Stohl, A., Wernli, H., James, P., Forster, C., and Spichtinger, N.: A 15-year climatology of warm conveyor belts, J. Climate, 17, 218-237, 2004.

Emanuel, K. A. and Živković-Rothman, M.: Development and evaluation of a convection scheme for use in climate models, J. Atmos. Sci., 56, 1766-1782, 1999.

Engler, C., Rose, D., Wehner, B., Wiedensohler, S. A., Br/'uggemann, E., Gnauk, T., Spindler, G., Tuch, T., and Birmili, W.: Size distribution of non-volatile particle residuals $\left(\mathrm{D}_{p}<800 \mathrm{~nm}\right)$ at a rural site in Germany and relation to air mass origin, Atmos. Chem. Phys. Discuss., 6, 5505-5542, 2006, http://www.atmos-chem-phys-discuss.net/6/5505/2006/.

Feldpausch, P, Fiebig, M., Fritzsche, L., and Petzold, A.: Measurement of ultrafine aerosol size distributions by a combination of diffusion screen separators and condensation particle counters, J. Aerosol Sci., 37, 577-597, doi:10.1016/j.jaerosci.2005.04.009, 2006.

Fiebig, M.: The tropospheric aerosol at mid-latitudes - microphysics, optics and climate forcing illustrated by the LACE 98 field study, Doctoral thesis Ludwig-Maximilians-University Munich, DLR Research report FB 2001-23, 259 pages, 2001.

Fiebig, M., Petzold, A., Wandinger, U., Wendisch, M., Kiemle, C., Stifter, A., Ebert, M., Rother, T., and Leiterer, U.: Optical closure for an aerosol column: Method accuracy, and inferable properties applied to a biomass-burning aerosol and its radiative forcing, $\mathrm{J}$. Geophys. Res., 107, 8130, doi:10.1029/2000JD000192, 2002.

Forster, C., Wandinger, U., Wotawa, G., James, P., Mattis, I., Althausen, D., Simmonds, P., O'Doherty, S., Kleefeld, C., Jennings, S. G., Schneider, J., Trickl, T., Kreipl, S., Jäger, H., Stohl, A.: Transport of boreal forest fire emissions from Canada to Europe, J. Geophys. Res., 106, 22 887-22 906, 2001.

Forster, C., Cooper, O., Stohl, A., Eckhardt, S., James, P., Dunlea, E., Nicks Jr., D. K., Holloway, J. S., Hübler, G., Parrish, D. D., Ryerson, T. B., and Trainer, M.: Lagrangian transport model forecasts and a transport climatology for the Intercontinental Transport and Chemical Transformation 2002 (ITCT 2k2) measurement campaign. J. Geophys Res. 109, D07S92, doi:10.1029/2003JD003589, 2004.

Forster, C., Stohl, A., and Seibert, P.: Parameterization of convec- tive transport in a Lagrangian particle dispersion model and its evaluation, J. Appl. Meteor., in press, 2007.

Frost, G. J., McKeen, S. A., Trainer, M., Ryerson, T. B., Neuman, J. A., et al.: Effects of changing power plant NOx emissions on ozone in the eastern United States: Proof of concept, J. Geophys Res., 111, D12306, doi:10.1029/2005JD006354, 2006.

Gerbig, C., Kley, D., Volz-Thomas, A., Kent, J., Dewey, K., and McKenna, D. S.: Fast response resonance fluorescence CO measurements aboard the C-130: Instrument characterization and measurements made during North Atlantic Regional Experiment 1993, J. Geophys. Res., 101, 29 229-29 238, 1996.

Giglio, L., Descloitres, J., Justice, C. O., and Kaufman, Y.: An enhanced contextual fire detection algorithm for MODIS, Rem. Sens. Environ., 87, 273-282, 2003.

Grousset, F., Ginoux, P., Bory, A., and Biscaye, P.: Case study of a Chinese dust plume reaching the French Alps, Geophys. Res. Lett., 30, 1277, doi:10.1029/2002GL016833, 2003.

Hansen, M., DeFries, R., Townshend, J. R. G., and Sohlberg, R.: Global land cover classification at $1 \mathrm{~km}$ resolution using a decision tree classifier, Intern. J. Rem. Sensing., 21, 1331-1365, 2000.

Haywood, J. M., Osborne, S. O., Francis, P. N., Keil, A., Formenti, P., Adreae, M. O., and Kaye, P. H.: The mean physical and optical properties of regional haze dominated by biomass burning aerosol measured from the C-130 aircraft during SAFARI 2000, J. Geophys. Res., 108, 8473, doi:1029/2002JD002226, 2003.

Honrath, R. E., Owen, R. C., Val Martin, M., Reid, J. S., Lapina, K., Fialho, P., Dziobak, M. P., Kleissl, J., and Westphal, D. L.: Regional and hemispheric impacts of anthropogenic and biomass burning emissions on summertime $\mathrm{CO}$ and $\mathrm{O}_{3}$ in the North Atlantic lower free troposphere, J. Geophys. Res., 109, D24310, doi:10.1029/2004JD005147, 2004.

Hudman R. C., Jacob, D. J., Cooper, O. R., Evans, M. J., Heald, C. L., et al.: Ozone production in transpacific Asian pollution plumes and implications for ozone air quality in California, J. Geophys. Res., 109, D23S10, doi:10.1029/2004JD004974, 2004.

Huntrieser, H., Heland, J., Schlager, H., Forster, C., Stohl, A., Aufmhoff, H., Arnold, F., Scheel, H. E., Campana, M., Gilge, S., Eixmann, R., and Cooper, O.: Intercontinental air pollution transport from North America to Europe: Experimental evidence from aircraft measurements and surface observations, J. Geophys. Res., 110, DO1305, doi:10.1029/2004JD005045, 2005.

Husar, R. B., Tratt, D. M., Schichtel, B. A., Falke, S. R., Li, F., et al.: Asian dust events of April 1998, J. Geophys. Res., 106, 18 317-18 330, 2001.

Jacob, D. J., Logan, J. A., and Murti, P. P.: Effect of rising Asian emissions on surface ozone in the United States, Geophys. Res. Lett., 26, 2175-2178, 1999.

Jaffe, D., Anderson, T., Covert, D., Kotchenruther, R., Trost, B., Danielson, J., Simpson, W., Berntsen, T., Karlsdottir, S., Blake, D., Harris, J., Carmichael, G., and Uno, I.: Transport of Asian air pollution to North America, Geophys. Res. Lett., 26, 711- 714, 1999.

Koike, M., Kondo, Y., Kita, K., Takegawa, N., Masui, Y., et al.: Export of anthropogenic reactive nitrogen and sulfur compounds from the East Asia region in spring, J. Geophys. Res., 108(D20), 8789, doi:10.1029/2002JD003284, 2003.

Lawrence, M. G., Rasch, P. J., von Kuhlmann, R., Williams, J., Fis- 
cher, H., de Reus, M., Lelieveld, J., Crutzen, P. J., Schultz, M., Stier, P., Huntrieser, H., Heland, J., Stohl, A., Forster, C., Elbern, H., Jakobs, H., and Dickerson, R. R.: Global chemical weather forecasts for field campaign planning: predictions and observations of large-scale features during MINOS, CONTRACE and INDOEX. Atmos. Chem. Phys. 3, 267-289, 2003.

Lelieveld, J., Berresheim, H., Borrmann, S., Crutzen, P. J., Dentener, F. J., Fischer, H., Feichter, J., Flatau, P. J., Heland, J., Holzinger, R., Korrmann, R., Lawrence, M. G., Levin, Z., Markowicz, K. M., Mihalopoulos, N., Minikin, A., Ramanathan, V., de Reus, M., Roelofs, G. J., Scheeren, H. A., Sciare, J., Schlager, H., Schultz, M., Siegmund, P., Steil, B., Stephanou, E. G., Stier, P., Traub, M.,Warneke, C.,Williams, J., and Ziereis, H.: Global Air Pollution Crossroads over the Mediterranean, Science, 298, 794-799, 2002.

Li, Q. B., Jacob, D. J., Bey, I., Palmer, P. I., Duncan, B. N., Field, B. D., Martin, R. V., Fiore, A. M., Yantosca, R. M., Parrish, D. D., Simmonds, P. G., Oltmans, S. J.: Transatlantic transport of pollution and its effects on surface ozone in Europe and North America, J. Geophys. Res., 107, 4166, doi:10.1029/2001JD001422, 2002.

McMillan, W. W., Barnet, C., Strow, L., Chahine, M. T., McCourt Comer, M., Novelli, P. C., Krontzi, S., Maddy, E. S., and Datta, S.: Daily Global Maps of Carbon Monoxide: First Views from NASA's Atmospheric Ifrared Sounder, Geophys. Res. Lett., 32, L11801, doi:10.1029/2004GL012821, 2005.

Miyazaki, Y., Kita, K., Kondo, Y., Koike, M., Ko, M., et al.: Springtime photochemical ozone production observed in the upper troposphere over east Asia, J. Geophys. Res., 108(D3), 8398, doi:10.1029/2001JD000811, 2003.

Miyazaki, Y., Kondo, Y., Koike, M., Fuelberg, H. E., Kiley, C. M., et al: Synoptic-scale transport of reactive nitrogen over the western Pacific in spring, J. Geophys. Res., 108, 8788, doi:10.1029/2002JD003248, 2003.

Olivier, J. G. J. and Berdowski, J. J. M.: Global emissions sources and sinks, in: The Climate System, edited by: Berdowski, J., Guicherit, R., and Heij, B. J., pp. 33-78. A.A. Balkema Publishers/Swets \& Zeitlinger Publishers, Lisse, The Netherlands. ISBN $9058092550,2001$.

Parrish, D. D., Trainer, M., Buhr, M. P., Watkins, B. A., and Fehsenfeld, F. C.: Carbon monoxide concentrations and their relation to concentrations of total reactive oxidized nitrogen at two rural U.S. sites, J. Geophys. Res., 96, 9309-9320, 1991.

Parrish, D. D., Holloway, J. S., Trainer, M., Murphy, P. C., Forbers, G. L., and Fehsenfeld, F. C.: Relationships between ozone and carbon monoxide at surface sites in the North Atlantic region, J. Geophys. Res., 103, 13 357-13 376, 1998.

Parrish, D. D., Holloway, J. S., Jakoubek, R., Trainer, M., Ryerson, T. B., Hübler, G., Fehsenfeld, F. C., Moody, J. L., and Cooper, O. R.: Mixing of anthropogenic pollution with stratospheric ozone: A case study from the North Atlantic wintertime troposphere, J. Geophys. Res., 105, 24 363-24 374, 2000.

Perry, K. D. and Hobbs, P. V.: Further evidence for particle nucleation in clear air adjacent to marine cumulus clouds, J. Geophys. Res., 99, 22 803-22 818, 1994.

Petzold, A., Fiebig, M., Flentje, H., Keil, A., Leiterer, U., Stifter, A., Wendisch, M., and Wendling P.: Vertical variability of aerosol properties observed at a continental site during LACE 98, J. Geophys. Res., 107, 8128, doi:10.1029/2001JD001043, 2002.
Pfister G., Petron, G., Emmons, L. K., Gille, J. C., Edwards, D. P., et al.: Evaluation of $\mathrm{CO}$ simulations and the analysis of the CO budget for Europe, J. Geophys. Res., 109, D19304, doi:10.1029/2004JD004691, 2004.

Price, H. U., Jaffe, D. A., Cooper, O. R., and Doskey, P. V.: Photochemistry, ozone production, and dilution during long-range transport episodes from Eurasia to the northwest United States, J. Geophys. Res., 109, D23S13, doi:10.1029/2003JD004400, 2004.

Reeves, C. E., Claire, E., Penkett, S. A., et al.: Potential for photochemical ozone formation in the troposphere over the North Atlantic as derived from aircraft observations during ACSOE, J. Geophys. Res., 107, 4707, doi:10.1029/2002JD002415, 2002.

Russo, R. S., Talbot, R. W., Dibb, J. E., Scheuer, E., Seid, G., Jordan, C. E., Fuelberg, H. E., Sachse, G. W., Avery, M. A., Vay, S. A., Blake, D. R., Blake, N. J., Atlas, E., Fried, A., Sandholm, S. T., Tan, D., Singh, H. B., Snow, J., and Heikes, B. G.: Chemical composition of Asian continental outflow over the western Pacific: Results from Transport and Chemical Evolution over the Pacific (TRACE-P), J. Geophys. Res., 108, 8804, doi:10.1029/2002JD003184, 2003.

Schlager, H., Konopka, P., Schulte, P., Schumann, U., Ziereis, H., et al.: In situ observations of air traffic emission signatures in the North Atlantic flight corridor, J. Geophys. Res., 102, 10739 10750, 1997.

Schröder, F. P. and Ström, J.: Aircraft measurements of sub micrometer aerosol particles $(>7 \mathrm{~nm})$ in the midlatitude free troposphere and tropopause region, Atmos. Res., 44, 333-356, 1997.

Seibert, P. and Frank, A.: Source-receptor matrix calculation with a Lagrangian particle dispersion model in backward mode, Atmos. Chem. Phys., 4, 51-63, 2004, http://www.atmos-chem-phys.net/4/51/2004/.

Stohl, A.: A one-year Lagrangian "climatology" of airstreams in the northern hemisphere troposphere and lowermost stratosphere, J. Geophys. Res., 106, 7263-7279, 2001.

Stohl, A. (Ed.): Intercontinental Transport of Air Pollutants. Springer-Verlag, Heidelberg, ISBN: 3-540-20563-2, 325p, 2004.

Stohl, A., Hittenberger, M., and Wotawa, G.: Validation of the Lagrangian particle dispersion model FLEXPART against large scale tracer experiment data, Atmos. Environ., 32, 4245-4264, 1998.

Stohl, A. and Thomson, D. J.: A density correction for Lagrangian particle dispersion models, Boundary-Layer Meteorol., 90, 155167, 1999.

Stohl, A. and Trickl, T.: A textbook example of long-range transport: Simultaneous observation of ozone maxima of stratospheric and North American origin in the free troposphere over Europe, J. Geophys. Res., 104, 30 445-30 462, 1999.

Stohl, A., Eckhardt, S., Forster, C., James, P., and Spichtinger, N.: On the pathways and timescales of intercontinental air pollution transport, J. Geophys. Res., 107, 4684, doi:10.1029/2001JD001396, 2002.

Stohl, A., Trainer, M., Ryerson, T., Holloway, J., and Parrish, D.: Export of NOy from the North American boundary layer during NARE 96 and NARE 97, J. Geophys. Res. 107, 4131, doi:10.1029/2001JD000519, 2002.

Stohl, A., Forster, C. Eckhardt, S., Spichtinger, N., Huntrieser, H., Heland, J., Schlager, H., Wilhelm, S., Arnold, F., and Cooper, O.: A backward modeling study of intercontinental pollution trans- 
port using aircraft measurements, J. Geophys. Res., 108, 4370, doi:10.1029/2002JD002862, 2003.

Stohl, A., Forster, C., Frank, A., Seibert, P., and Wotawa, G.: Technical note: The Lagrangian particle dispersion model FLEXPART version 6.2., Atmos. Chem. Phys., 5, 2461-2474, 2005, http://www.atmos-chem-phys.net/5/2461/2005/.

Stohl, A., Berg, J. F. Burkhart, T., Fjæraa, A. M., Forster, C., Herber, A., Hov, Ø, Lunder, C., McMillan, W. W., Oltmans, S., Shiobara, M., Simpson, D., Solberg, S., Stebel, K., Ström, J., Tørseth, K., Treffeisen, R., Virkkunen, K., and Yttri, K.-E.: Arctic smoke - record high air pollution levels in the European Arctic due to agricultural fires in Eastern Europe, Atmos. Chem. Phys., 7, 511534, 2007, http://www.atmos-chem-phys.net/7/511/2007/.

Stull, R. B.: An Introduction to Boundary Layer Meteorology, Kluwer Academic Publishers, Dordrecht, 1988.

Takegawa, N., Kondo, Y., Koike, M., Chen, G., Machida, T., et al.: Removal of NOx and NOy in Asian outflow plumes: Aircraft measurements over the western Pacific in January 2002, J. Geophys. Res., 109, D23S04, doi:10.1029/2004JD004866, 2004.

Traub, M., Fischer, H., de Reus, M., Kormann, R., Heland, J., Ziereis, H., Schlager, H., Holzinger, R., Williams, J., Warneke, C., de Gouw, J., and Lelieveld, J.: Chemical characteristics assigned to trajectory clusters during the MINOS campaign, Atmos. Chem. Phys., 3, 459-468, 2003,

http://www.atmos-chem-phys.net/3/459/2003/.
Trickl, T., Cooper, O., Eisele, H., James, P.,Mücke, R., and Stohl, A: Intercontinental transport and its influence on the ozone concentrations over central Europe: Three case studies, J. Geophys. Res., 108, 8530, doi:10.1029/2002JD002735, 2003.

Wang, T., Cheung, T. F., Li, Y. S., Yu, X. M., and Blake, D. R.: Emission characteristics of $\mathrm{CO}, \mathrm{NO}_{\mathrm{X}}, \mathrm{SO}_{2}$ and indications of biomass burning observed at a rural site in eastern China, J. Geophys. Res., 107, 4157, doi:10.1029/2001JD000724, 2002.

White, P. W. (Ed.): IFS Documentation, ECMWF, Reading, UK, 2002.

Wild, O. and Akimoto, H.: Intercontinental transport of ozone and its precursors in a three-dimensional global CTM, J. Geophys. Res., 106, 27 729-27 744, 2001.

Wotawa, G. and Trainer, M.: The Influence of Canadian Forest Fires on Pollutant Concentrations in the United States, Science, 288, 324-328, 2000.

Ziereis, H., Schlager, H., Schulte, P., Köhler, I., Marquardt, R., and Feigl, C.: In situ measurements of the NOx distribution and variability over the eastern North Atlantic, J. Geophys. Res., 104, 16021-16 032, 1999. 